\title{
Paleoenvironmental context and significance of a partial elasmosaurid skeleton from the Albian of Haute-Provence, France
}

Peggy Vincent ${ }^{\mathrm{a}}{ }^{*}$, Anne-Sabine Grosjean ${ }^{\mathrm{b}}$, Didier Bert ${ }^{\mathrm{c}}$, , Jorge Ferreira ${ }^{\mathrm{d}}$, Baptiste SuchérasMarx $^{\mathrm{e}}$, Guillaume Suan ${ }^{\mathrm{d}}$, Guillaume Guinot ${ }^{\mathrm{f}}$, Vincent Perrier ${ }^{\mathrm{d}}$, Kévin Janneau ${ }^{\mathrm{g}}$, Jean-Michel Brazier $^{\mathrm{h}}$, Estel Sarroca ${ }^{\mathrm{b}}$, Myette Guiomar ${ }^{\mathrm{c}}$, Jeremy E. Martin ${ }^{\mathrm{d}}$

a Sorbonne Université (CNRS-MNHN-UPMC) - Muséum national d'Histoire naturelle, Département Origines et Evolution, UMR CNRS-MNHN-UPMC 7207, Centre de Recherche en Paléontologie-Paris (CR2P), 57, rue Cuvier - 75231 Paris Cedex 05, France.

${ }^{\mathrm{b}}$ Paleorhodania, 69006 Lyon - France.

${ }^{\mathrm{c}}$ Réserve naturelle nationale géologique de Haute-Provence, Conseil départemental des Alpes de Haute-Provence, Service environnement, Direction du développement, de l'environnement et de l'eau, 13, rue du docteur Romieu - CS 7021604995 Digne-les-Bains Cedex 9, France.

${ }^{\mathrm{d}}$ Université de Lyon, UCBL, ENSL, CNRS, UMR 5276 LGL-TPE, 69622 Villeurbanne, France.

${ }^{\mathrm{e}}$ Aix Marseille Univ, CNRS, IRD, INRA, Coll France, CEREGE, Aix-en-Provence, France.

${ }^{\mathrm{f}}$ Université de Montpellier, CNRS, IRD, EPHE (UM), Institut des Sciences de l'Evolution de Montpellier, 163 rue Auguste Broussonnet - 34090 Montpellier, France.

${ }^{\mathrm{g}}$ Université de Strasbourg (UNISTRA), Jardin des sciences, 12 rue de l'Université, 67000 Strasbourg, France.

${ }^{\mathrm{h}}$ Institute of Applied Geosciences, Graz University of Technology, Rechbauerstrasse 12, A8010, Graz, Austria.

${ }^{\mathrm{i}}$ Laboratoire Géosciences, UMR-CNRS 6118, Université de Rennes-1, campus Beaulieu, bâtiment 15, F-35042 Rennes cedex, France.

* Corresponding author; peggy.vincent@mnhn.fr

\begin{abstract}
The Early-Late Cretaceous transition (late Albian-early Cenomanian; 100 Ma) witnessed marked environmental changes and a deep reorganization of the marine fauna. The impact of these environmental and biotic changes on Tethyan marine vertebrates is poorly understood, due to a fragmentary fossil record. Here we report upper Albian marine vertebrate remains, including a partially articulated plesiosaurian skeleton, from a fossiliferous glauconite-rich bed in the Alpes de Haute-Provence, France. The fossiliferous horizon produced a diversified invertebrate fauna including ammonoids and belemnoids. The ammonite fauna is abundant and diversified, indicating the Mortoniceras fallax ammonite Zone. The calcareous nannofossil biomarkers date the bed to the NC10a Zone. The fossiliferous bed consists of glauconitic marls enriched in planktic foraminifera and occurs amongst a monotonous succession of alternating marlstones and limestone beds. The vertebrate fauna consists of chondrichthyans and marine reptiles. Chondrichthyans are represented by five Lamniformes species (dominated by Sphenodus) and comprise predator taxa probably living in open marine temperate waters. The site yielded a large, partial post-cranial plesiosaurian skeleton with articulated elements belonging to an elasmosaurid and representing one of the most complete Albian plesiosaurian specimens known from Europe. The abundance and preservation of the collected fossil remains are best explained by their concentration during a basin-scale episode of very low sedimentation corresponding to a major episode of marine transgression, associated with a lower oxygenation of bottom waters. These findings indicate that the newly
\end{abstract}


discovered fossiliferous bed holds promising clues about the evolutionary history of major groups of marine vertebrates and ammonites near the Early-Late Cretaceous transition.

\section{Key words}

Albian, Cretaceous, southeastern France, marine reptiles, Plesiosauria, glauconite bed, Konzentrat-Lagerstätte, Réserve Naturelle Nationale Géologique de Haute-Provence

\section{Introduction}

The Cretaceous period saw the diversification and widespread geographic dispersal of several groups of emblematic marine tetrapods, including marine turtles, marine crocodylomorphs, ichthyosaurs, plesiosaurs and mosasaurs (e.g., Bardet et al., 2014; Fischer et al., 2014; Martin et al., 2014; Nicholson et al., 2015). In parallel, geochemical studies have shown that this time interval was characterized by very warm conditions, punctuated by episodes of exceptional warmth (early Aptian, Cenomanian-Turonian) and transient cooling (late Valanginian, late Aptian and early Maastrichtian; Pucéat et al., 2003; Bodin et al., 2015; O'Brien et al., 2017). The 'mid-Cretaceous' interval has been commonly characterized as a time of prevailing greenhouse conditions with both surface- and bottom-water temperatures markedly higher than that of modern oceans (Scott et al., 2013). The sea level was much higher than today (Haq et al., 1987), and many areas were marked by relatively short-lived events of surface-water stratification and black shale deposition known as Oceanic Anoxic Events (OAEs; Schlanger and Jenkyns, 1976). One prominent example of such events is the OAE1d recorded near the Albian-Cenomanian transition and regionally identified in the Vocontian Basin SE France as a discrete interval of organic-rich shales known as the 'Niveau Breistroffer' (Bornemann et al., 2005).

Regarding marine reptiles, the Cretaceous fossil record displays major gaps that hamper detailed comparisons with sedimentary and geochemical records. This is particularly true for the upper part of the lower Cretaceous, which record marked oceanic and climatic perturbations but contain rare remains of marine reptiles often represented by isolated bones or incomplete and disarticulated specimens from bonebed-like, reworked deposits (Buffetaut et al., 1981; Bardet et al., 2014). Ichthyosauria experienced a deep reorganization and a marked decrease in diversity near the Albian-Cenomanian transition (Fischer et al., 2016), and different phases of ammonoid turnovers have been reported during the late Albian interval (Reboulet et al., 2011; Gale et al., 2011). Despite these evidences for major changes affecting upper trophic levels, the scarcity of fossiliferous sites for this period (Bardet et al., 2014; Benson et al., 2010) hampers a full appraisal of the timing and modality of biotic changes in marine vertebrates at the end of the Early Cretaceous.

The area around Digne-les-Bains in SE France is renowned for its geoheritage and paleontological sites (RNNGHP: Réserve Naturelle Nationale Géologique de HauteProvence) and includes, among other Mesozoic strata, extensive exposures of upper Albian successions. In this study, we report the discovery of a new Albian marine fossiliferous horizon, including a partial plesiosaur skeleton, near the village of Tartonne in the RNNGHP. This horizon revealed a rich ammonite and nannofossil record, allowing for a precise biostratigraphic control. The aims of this study are to: (i) describe and identify the Tartonne biotic assemblage, (ii) characterize its environmental and post-depositional conditions, and (iii) discuss the perspectives of the new findings for our understanding of the evolution of marine reptiles at the end of the Early Cretaceous.

Institutional Abbreviations- AMNH, American Museum of Natural History, New York, NY, USA; CM, Canterbury Museum, Christchurch, New Zealand; MGUAN, Museu de Geologia da Universidade Agostinho Neto, Luanda, Angola; MML, Museo Municipal de Lamarque, 
Río Negro, Argentina; NZGS, New Zealand Geological Survey, Lower Hutt, New Zealand; SGO.PV., Paleontología de Vertebrados, Museo Nacional de Historia Natural, Santiago, Chile; SMNK, Staatliches Museum für Naturkunde Karlsruhe, Germany.
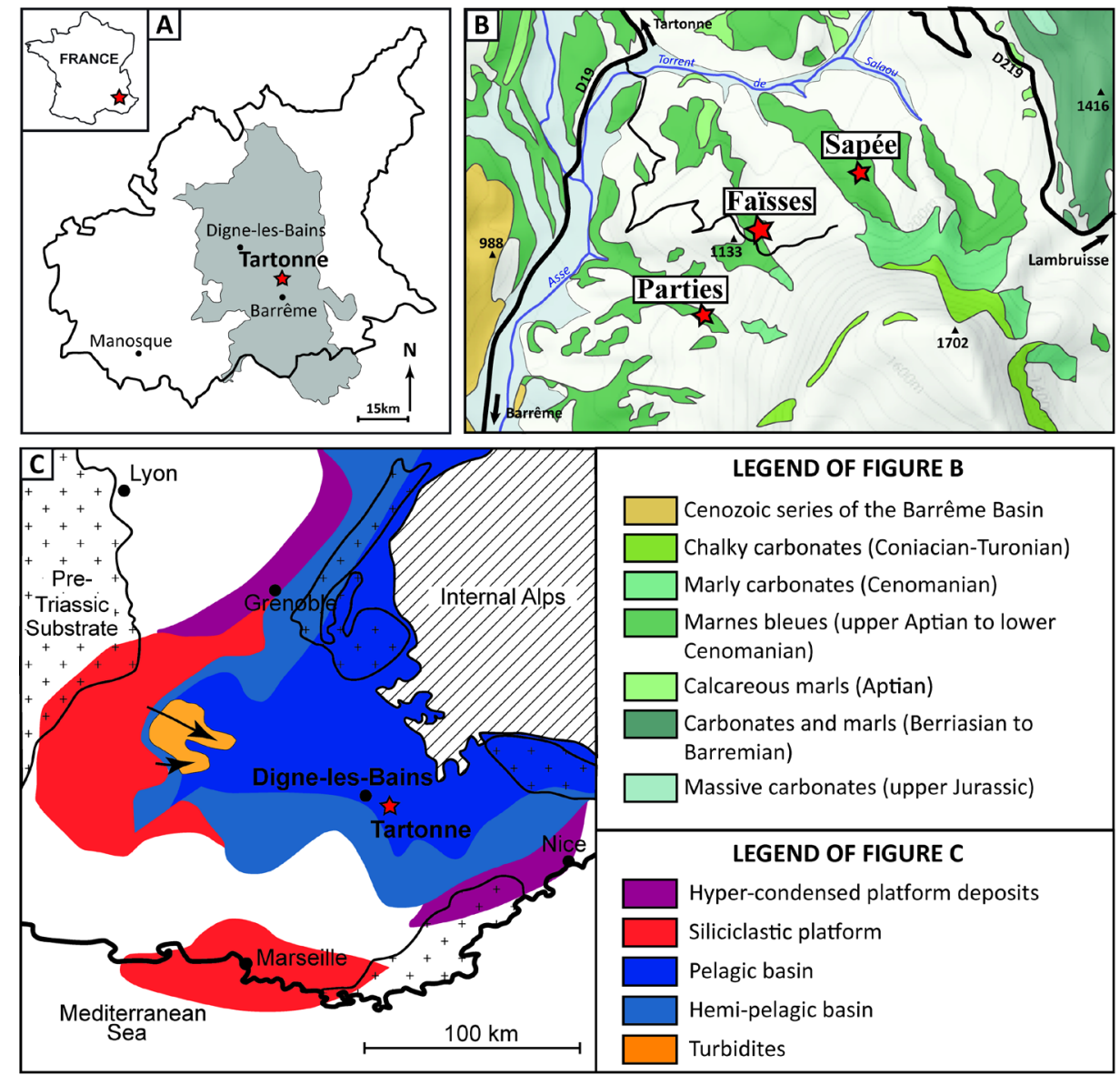

Figure 1. A. Location of the study area (star) in France. B. Location of the studied sections (stars) in the department of Alpes de Haute-Provence. C. Paleogeographic location of the study area (star) within the Cretaceous French Subalpine Basin (modified from Bréhéret, 1997 and Amédro, 2008).

\section{Geological and stratigraphic setting}

The studied section, named Les Faïsses section, is located in the municipality of Tartonne, $12 \mathrm{~km}$ north of Barrême, Alpes de Haute-Provence (SE France, Figs 1A and 1B). The succession belongs to the Marnes Bleues Formation, a $800 \mathrm{~m}$ thick upper Aptian to lower Cenomanian succession of dark gray pelagic marlstones and argillaceous marlstones (Gale et al., 2011; Fig. 1B). The uppermost part of the upper Albian has been also informally attributed to the Vraconnian, a regional stage absent from international stratigraphic charts (Ogg et al., 2016), but commonly mapped and used for regional studies (e.g., Kerckhove and Roux, 1976; Amédro, 2008). Amédro (2008) proposed the Vraconnian as a stage differentiated from the upper Albian sensu stricto (s.s.) and spanning the upper Albian, from the base of the M. fallax ammonite Zone to the base of the Cenomanian. Several stratigraphic and mapping studies have been realized on the Albian s.s. and the Vraconnian of French Subalpine Basin since the $20^{\text {th }}$ century (e.g., Elloy and Faber, 1962; Cotillon, 1971; Tronchetti, 1981; Rubino and Delamette, 1985; Friès, 1987; Bréhéret, 1997) allowing a good temporal and spatial control. Some localities have been studied at high resolution for bio-, chemo-, and cyclo-stratigraphy such as the sections of Salazac (Latil, 1995; Amédro, 2008), Montlaux (Kennedy and Latil, 2007), Mont-Risou (Gale et al., 1996), Col de Palluel (Gale et 
al., 2011), Hyèges and Moriez (Gyawali et al., 2017). The Vraconnian notably includes the Breistroffer level OAE1d, which has been intensively studied to assess the impact of decreasing oxygenation on marine organisms (Giraud et al., 2003; Bornemann et al., 2005; Reboulet et al., 2005; Bornemann and Mutterlose, 2006; Mutterlose et al., 2009).

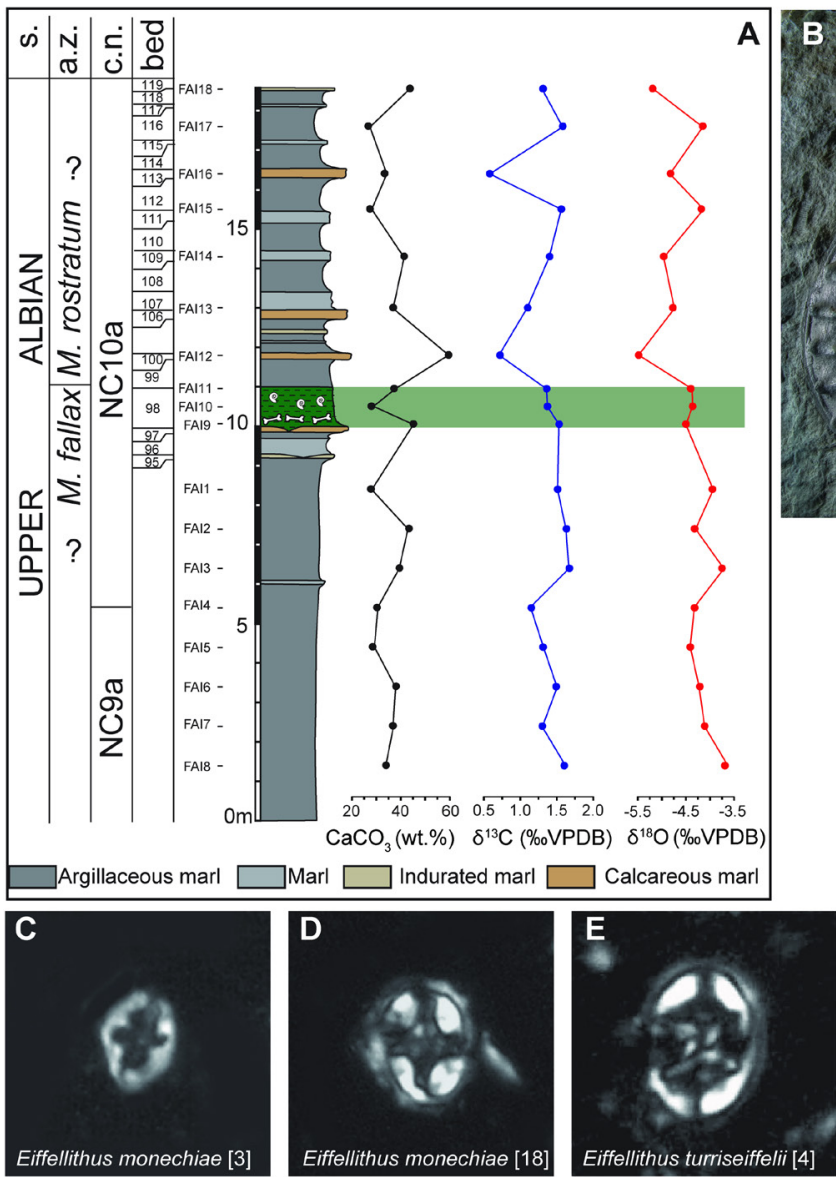

Figure 2. Bio- and chemostratigraphic data of Les Faïsses section. A. Lithology, calcium carbonate contents, bulk carbonate carbon and oxygen isotope compositions and biostratigraphy (S: Stage; AZ: Ammonite zones; CN: Calcareous nannofossil biostratigraphy). B. Mortoniceras fallax (Breistroffer, 1940), deposited in the RNNGHP (RNNGHP.04214-TA.131); fossiliferous glauconite-rich bed $98 \mathrm{D}=270 \mathrm{~mm}$ (without keel and rostrum). C-E. Photographs of some coccoliths observed in Les Faïsses samples (sample number in bracket). Full plate in Supplementary Material.

The transition from the upper Albian s.s. to the Vraconnian records a strong change in depositional dynamics within the French Subalpine Basin. The sedimentation during the upper Albian-lower Cenomanian was characterized by the deposition of micaceous sandstones coming from the emerged Durancian Isthmus in a low subsiding transgressive context (Masse and Philip, 1976; Masse et al., 1990). Cotillon (1971) noted the accumulation of glauconite lenses interbedded within sandstones and interpreted them as contourites, i.e., deep-water deposits formed by strong bottom-currents. The Vraconnian records the recovery of the carbonate-dominated pelagic sedimentation where detrital influxes are commonly interbedded. Bréhéret (1997) correlated the base of the Vraconnian to the post-Durancian uplift major transgression and interpreted the OAE1d (Niveau Breistroffer) as a maximum flooding surface. North and south of the French Subalpine Basin, channelized Albian successions rich in glauconite and phosphorite have been described in the southern Helvetic domain and in the Arc de Nice area (Alpes-Maritimes, SE France); glauconitic sandstones and 
condensed successions have been reported in Albian strata of the Jura platform (Delamette, 1988) and the Nice flooded platform (e.g., Barale et al., 2015). The comparison of these unusual, glauconite-rich and condensed successions of the northern Tethyan margin suggests that the whole area was prone to strong, subsurface N-S unidirectional currents (Delamette, 1988).

The Tartonne area corresponds to the pelagic domain of the French Subalpine Basin, dominated by a marly sedimentation with variable concentrations of calcium carbonate (Fig. 1C). Les Faïsses section is characterized by the presence of a massive one meter-thick greenish-gray bed, in which the exceptional concentration of fossil remains was discovered. This peculiar level is referred in the present study as the 'glauconite-rich bed' (bed 98 in Fig. 2A) and seems laterally continuous, as it has also been observed in two other ravines (i.e., Les Parties and La Sapée ravines) located within a distance of $400 \mathrm{~m}$ from the main study site (Fig. 1B). The lithology and fossil content of the glauconite-rich bed clearly stand out from other beds of the Marnes Bleues Formation, suggesting its deposition resulted from unusual environmental and diagenetic conditions. The glauconite-rich bed is stratigraphically constrained to the base of the Vraconnian regional stage according to previous studies (Cotillon, 1971; Bréhéret, 1997), but, to our knowledge, its fossil content and sedimentological features have not been described yet.

\section{Material and methods}

\subsection{Ammonite and calcareous nannofossil assemblages}

The green fossiliferous glauconite-rich bed has yielded a very rich ammonite fauna often with large specimens. The largest collected ammonite is Puzosia mayoriana (d'Orbigny, 1841) with a $700 \mathrm{~mm}$ diameter. Despite the poor preservation of small specimens, and post mortem compression of some specimens (however less intense than in the overlying marlstones) and frequent presence of incomplete specimens, this fauna is quite exceptional for several reasons. First, many specimens are complete and include very fragile structures of the shell (e.g., spines, rostrum) that commonly break off during taphonomic processes. Secondly, the ammonite fauna is highly diverse (at least 14 genera) and will be detailed further in a forthcoming study. The presence of these ammonites ensures a precise dating of the fossiliferous levels, in particular, of the glauconite-rich bed 98 and the overlying marlstone bed 99. The specimens are curated in RNNGHP in Digne-les-Bains, France.

The biostratigraphic framework used in this work follows that proposed by the I.U.G.S. lower Cretaceous ammonite working group (the Kilian Group - Reboulet et al., 2011, 2014, 2018; Fig. 2A and Supplementary Data 1). The terminology follows the standards of the International Commission on Stratigraphy (Salvador, 1994).

A total of 18 samples were prepared for nannofossil biostratigraphic analysis. Smear slides were prepared using the standard Bown and Young (1998) technique and its nannofossil content analyzed under a standard light microscope with x1000 magnification. On average 800 fields of view were scanned for each sample. Abbreviation FO is used for the first or stratigraphically lowest occurrence of a species in the section whereas LO is used for the last or stratigraphically highest occurrence of a species in the section.

\subsection{Microfacies and ammonite shell mineralogy}

Three thin sections were prepared at CEREGE (Aix-en-Provence, France), for description of the glauconitic-rich bed microfacies and ammonite shells. The thin sections were observed on an Olympus BH-2 microscope, with objectives x4, x10, x20 and an ocular x10.

Ammonite shell layers were studied using a Hitachi S-3000N SEM and an EDS Brucker Nano XFlash detector $5010129 \mathrm{eV}$. The samples were coated with a thin layer of gold and palladium. Same samples were crushed down to a fine powder and deposited on low noise 
silicon sample holder to perform XRD analyses using a X'Pert Pro MPD diffractometer (PANalytical) equipped with a cobalt anticathode (lambda $=1.79 \AA$ ) operating at $40 \mathrm{kV}$ and $40 \mathrm{~mA}$. Sample holder rotated 15 round per minute. The green coating of ammonites was analyzed from $5^{\circ}$ to $75^{\circ}$ every $0.033^{\circ}$ with $2.5 \mathrm{~s}$ time analysis per point and the white crystalline layer was analyzed from $25^{\circ}$ to $60^{\circ}$ every $0.033^{\circ}$ with $2.5 \mathrm{~s}$ time analysis per point. Spectrum analyses were made using the software X'Pert HighScore + (PANalytical) using the database ICDD PDF2.

\subsection{Stable isotope and carbonate content measurements}

Calcium carbonate $\left(\mathrm{CaCO}_{3}\right)$ content (in wt.\%) and oxygen $\left(\delta^{18} \mathrm{O}\right)$ and carbon $\left(\delta^{13} \mathrm{C}\right)$ stable isotope compositions were measured on the same 18 bulk samples analyzed for calcareous nannofossil biostratigraphy. The amount of $\mathrm{CaCO}_{3}$ was determined from $100 \mathrm{mg}$ of bulk powder of each sample using an automatic calcimeter VF20 (Dream Electronique) with an uncertainty of $4 \mathrm{wt} . \%$. The oxygen and carbon stable isotope compositions were measured on powdered bulk sample using a Finnigan DELTAplus Advantage IRMS (isotope ratio mass spectrometer) at CEREGE. Each sample was duplicated, and the results are expressed in per mil relative to the Vienna Pee Dee Belemnite standard (\%o VPDB). Based on repeated measurements of the international reference NBS19, the average external reproducibility of $\delta^{18} \mathrm{O}$ and $\delta^{13} \mathrm{C}$ measurements are $0.06 \%$ and $0.04 \%$, respectively. Results are available in tabulated form in Table S1 (supplementary information).

\subsection{Vertebrate remains}

The fossiliferous horizon was discovered by one of us (MG) in 2015. At the time of discovery, only few skeletal elements of plesiosaurian affinities weathered out and detached from the hillside. Two field campaigns (July 2015 and 2016) revealed the presence of an incomplete plesiosaurian specimen associated with ichthyosaur and shark teeth, as well as numerous invertebrates (cephalopods, inoceramids, brachiopods). All the faunal remains described in this work were found within a few meters of the plesiosaurian skeletal remains (Fig. 3). The fossil vertebrates were partly extracted from their surrounding matrix and consolidated in the laboratory using pneumatic vibro-tool. All plesiosaurian remains, including 71 skeletal pieces, were grouped together under the inventory number RNNGHP.04214-TA.2015.1. Specimens are curated in the collections of the RNNGHP (Réserve Naturelle Nationale Géologique de Haute-Provence) in Digne-les-Bains, France. RNNGHP is a public structure created by Ministerial decree of the French State, and managed by the Departemental Council of the Alpes de Haute-Provence.

The ichthyofauna collected from the fossiliferous glauconite-rich bed (bed 98) and the overlying marlstone bed (bed 99 in Fig. 2A) mainly includes isolated chondrichthyan teeth. All these specimens were surface-collected during the excavation of the plesiosaur specimen. Several kilograms of sedimentary rocks sampled from the glauconite-rich bed were dissolved in acid and sieved, but no chondrichthyan remains were recovered.

\section{Results}

\subsection{Bio- and chemostratigraphy}

\subsubsection{Ammonite biostratigraphy}

The ammonite biostratigraphy of most of the upper Albian interval is based on the successive appearance of different species of the genus Mortoniceras (Meek, 1876). The genus Mortoniceras is derived from Dipoloceras (Hyatt, 1900) and forms a series of successive chronospecies with a very strong intraspecific variability. Its representatives were chosen as zonal indexes because of the evolution of their morphological characteristics. The intraspecific variability ranges from rather evolute, thick and strongly ornamented forms, to 
forms with finer ornamentation, which are more involute and slender. This appears to be a continuous variation of classical dipolar type (see Bert, 2013, fig. 1; Bert, 2014, p. 478; de Baets et al., 2015).
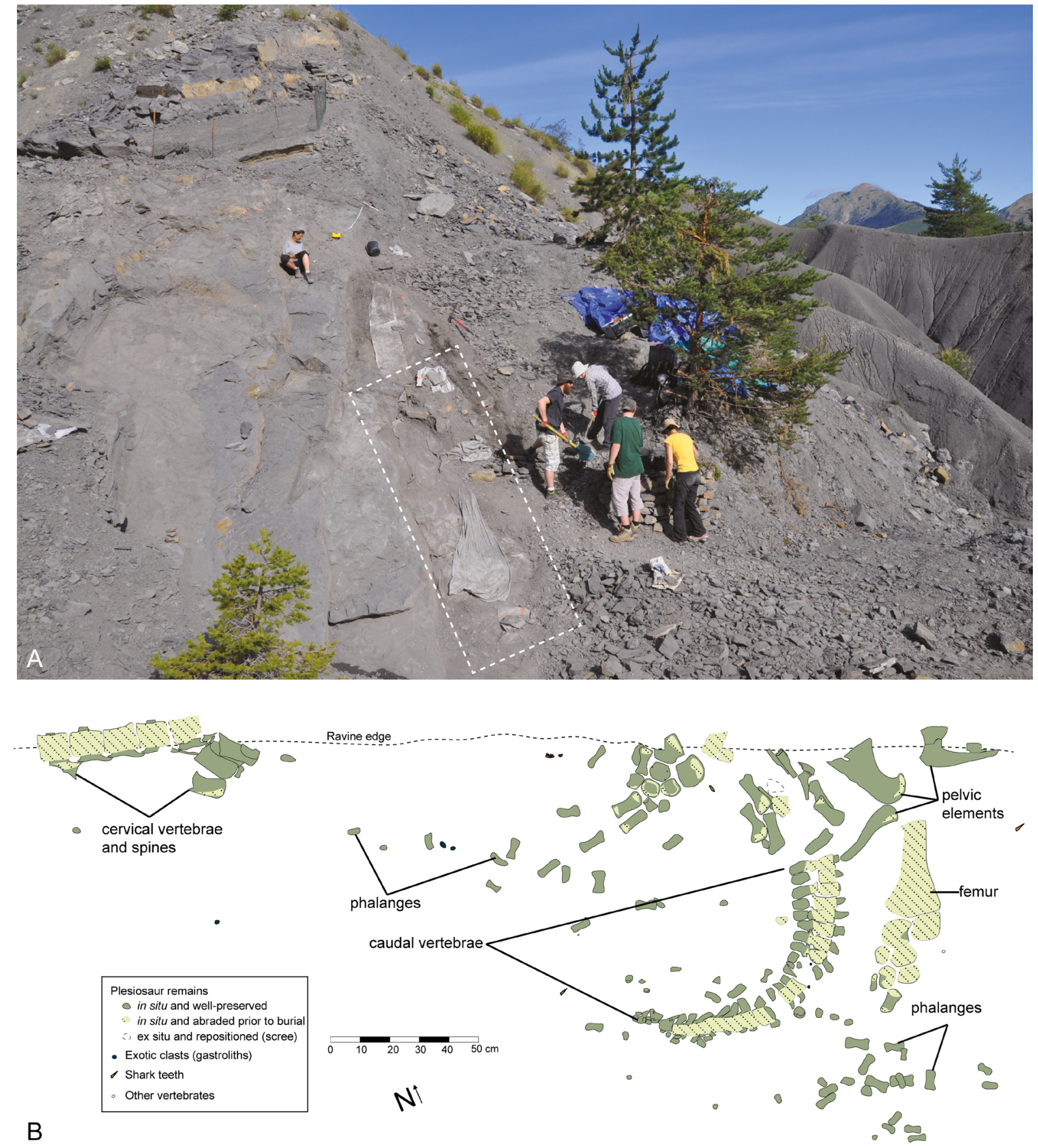

Figure 3. A. Field photograph of study site Les Faïsses. B. Sketch of the plesiosaur remains associated with other vertebrates based on field and preparation notes and photographs.

The succession over time of the zonal index species of Mortoniceras is as follows (Supplementary Data 1): Mortoniceras pricei (Spath, 1922), M. inflatum (Sowerby, 1817), M. fallax (Breistroffer, 1940), M. rostratum (Sowerby, 1817), and M. perinflatum (Spath, 1922). This diversification was likely achieved through a proterogenesis process (heterochrony), now well understood in this group (Amédro, 1980; Amédro et al., 2004; Kennedy and Latil, 2007; Owen, 2012). 
In Tartonne, the numerous Mortoniceras collected in the fossiliferous glauconite-rich bed show three tubercles per rib and a rostrum oriented perpendicular to the coiling direction of the shell. Through these characters, these ammonites belong to the species M. fallax (Fig. 2B). From the same bed, we can also mention the presence of M. nanum Spath, 1933, also bearing three tubercles per ribs, which could be the microconch sexual dimorph of $M$. fallax or a micromorphic autonomous species. Neophlycticeras (Neophlycticeras) blancheti (Pictet and Campiche, 1859) is also present in the glauconite-rich bed, although rare. The other ammonites (non-exhaustive list) are: Phylloceras seresitense Pervinquière, 1907, Tetragonites timotheanus (Pictet, 1847), Kossmatella munlenbecki (Fallot, 1885), Desmoceras latidorsatum (Michelin, 1838), Puzosia mayoriana, Cantabrigites minor (Spath, 1931), Scaphites sp., Hemiptychoceras subgaultinum Breistroffer, 1940, Anisoceras armatum (Sowerby, 1817), Anisoceras pseudoelegans (Pictet and Campiche, 1861), Anagaudryceras sacya (Forbes, 1846), Hamites sp. and Pseudhelicoceras aff. circumtaeniata (Kossmat, 1895).

The presence of this faunal assemblage in the glauconite-rich bed, indicates the Mortoniceras fallax Zone in the middle upper Albian (Fig. 2A). The overlying marlstone bed (99) is less fossiliferous but has yielded Mortoniceras rostratum (Supplementary Data 2).

\subsubsection{Calcareous nannofossil biostratigraphy}

All samples from Les Faïsses section yielded abundant, moderate to well-preserved calcareous nannofossils. Their presence/abundance are shown in Supplementary Data 3. The presence of the dissolution-sensitive taxa Scapholithus (syn. Calciosolenia) and the holococcoliths Owenia and Orastrum in almost all samples indicate a relatively good state of preservation. Species richness is high, averaging 54 taxa per sample and reaching maxima of more than 70 taxa in sample FAI 5. A total of 91 morphologies were identified throughout the section, including a new species of the genus Biscutum that needs to be defined in a future work. Four ever-present and common/abundant Rhagodiscus species (R. achlyostaurion, $R$. angustus, $R$. asper and R. splendens) are lumped under Rhagodiscus spp. The biostratigraphic scheme used in this work follows the Tethyan biostratigraphic NC zonation scheme from of Roth $(1978,1983)$ with subzones after Bralower et al. (1993) to facilitate comparisons with recent studies done in southeast France (Gale et al., 2011; Gyawali et al., 2017). Five bioevents have been identified: two first occurrences (FO) and three last occurrences (LO). A representative selection of specimens is illustrated in Fig. $2 \mathrm{C}$-E, Supplementary Data $4 \mathrm{~A}$ and $4 \mathrm{~B}$ and a complete taxonomic list of the species observed is given in Supplementary Data 5.

Comparisons of our results with previous studies of the Marnes Bleues Formation of the French Subalpine Basin reveal several differences in the stratigraphic position of some of these calcareous nannofossil bioevents. Considering the discontinuous nature of various biostratigraphically meaningful species reported here and in other studies, these differences arise, at least partly, from the variable number of samples and thicknesses of the successions analyzed in each study. The two main meaningful bioevents recorded in Les Faïsses are the FO of Eiffellithus monechiae and Eiffellithus turriseiffelii. Because E. turriseiffelii includes a plexus of transitional morphotypes (Watkins and Bergen, 2003; Shamrock and Watkins, 2009), all forms of Eiffellithus bearing symmetrical and diagonal stem base bars are informally grouped as E. turriseiffelii. The FO of Eiffellithus monechiae defines the base of nannofossil subzone NC9b and the FO of Eiffellithus turriseiffelii the base of NC10a (Roth, 1978, 1983; Bralower et al., 1993). However, the FO of these two species occur in the same sample (FAI 4), suggesting that the subzone NC9b is either extremely condensed, or that the 'true' FO of E. monechiae occurs in beds stratigraphically below the investigated interval. Given the patchy record of E. monechiae in this (Fig. 2C-D) and previous studies (Gale et al., 2011; Gyawali et al., 2017), the latter explanation seems most likely. Similarly, the LO of 
Chiastozygus platyrhethus is herein observed in the Mortoniceras fallax ammonite Zone, whereas it was recorded in the Mortoniceras perinflatum ammonite Zone by Gale et al. (2011). Again, this taxon is rare and further sampling of the beds stratigraphically younger than our measured section, might extend upwards its LO at the study site.

Some differences in the stratigraphic position of some bioevents are more difficult to explain solely by sampling biases: the LO of Crucicribrum anglicum corresponds to the FO of Eiffellithus turriseiffelii in our record, whereas this taxon is totally absent in the $150 \mathrm{~m}$-thick interval above the FO of E. turriseiffelii in the Moriez section, situated in this same basin $\sim 10 \mathrm{~km}$ south of the study site (Gyawali et al., 2017). Conversely, the LO of Crucicribrum anglicum occurs within the Mortoniceras pricei ammonite Zone, about $25 \mathrm{~m}$ below the FO of E. turriseiffelii, in the Ravin des Jassines section located northwestward from Les Faïsses in the French Subalpine Basin (Gale et al., 2011). The LO of this taxon was also reported in stratigraphically older beds in southern England by Bown (2001), Crux (1991) and Black (1972, 1973, 1975). Similarly, the LO of Hayesites albienses coincides with the FO of E. turriseiffelii at Les Faïsses but was recorded about $30 \mathrm{~m}$ below the FO of E. turriseiffelii in the M. pricei ammonite Zone at the Ravin des Jassines (Gale et al. (2011), and about $170 \mathrm{~m}$ above the FO of E. turriseiffelii at Moriez (Gyawali et al. 2017). These strong mismatches, if not linked to identification or preservation issues, suggest that $C$. anglicum and $H$. albienses flourished under some transient, site-specific peculiar environmental conditions and hence constitute poor biostratigraphic markers.

\subsubsection{Stable isotope analyses-Correlation and age of the fossiliferous site}

The chemostratigraphic data of Les Faïsses section are synthesized in Figure 2A. The

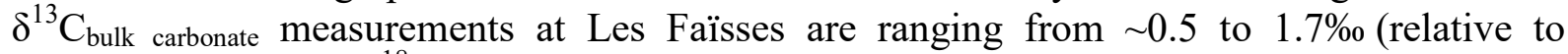
VPDB) whereas the $\delta^{18} \mathrm{O}_{\text {bulk carbonate }}$ measurements are ranging from $\sim-5.4$ to $-3.7 \%$ (relative to VPDB). Carbon isotope values fluctuate around $1.5 \%$ in the lower half of the measured section and record a $\sim 0.8 \%$ negative excursion starting above the fossiliferous glauconite-rich bed and reaching lowest values $(0.7 \%$ ) $1 \mathrm{~m}$ above its top. Oxygen isotope values record similar trends and show a relatively good positive correlation with $\delta^{13} \mathrm{C}_{\text {bulk carbonate values }}\left(\mathrm{R}^{2}=\right.$ $0.48)$.

The carbon isotope composition of bulk carbonate $\left(\delta^{13} \mathrm{C}_{\text {bulk carbonate }}\right)$ is widely used for stratigraphic correlation (Saltzman and Thomas, 2012). Although our $\delta^{13} \mathrm{C}_{\text {bulk carbonate }}$ data cover a relatively short stratigraphic interval, the recorded trends show some similarities with that published by Gyawali et al. (2017) for the Moriez section. These authors indeed reported a $\sim 0.8 \%$ negative $\delta^{13} \mathrm{C}_{\text {bulk carbonate }}$ excursion recorded just above a distinctive glauconite bed (base of their Unit II), which occurs $\sim 8 \mathrm{~m}$ below the FO of E. turriseiffelii and $\sim 25 \mathrm{~m}$ above the FO of E. monechiae. These isotopic and biostratigraphical similarities suggest that the studied fossiliferous glauconite-rich bed could be tentatively correlated with that reported by these authors. Our field observations also identified a glauconite-rich bed with large ammonite specimens in several places at Vergons and Angles, near Saint-André-les-Alpes, $\sim 20 \mathrm{~km}$ southeast of Tartonne, but assessing its more exact age requires further work. Various glauconitic beds, of similar age have been reported from other outcrops in the basin (Bréhéret, 1997) and also deserve further dating. On the western part of the basin at Salazac, proximal glauconitic sands deposits occur at the top of M. fallax ammonite Zone, which are therefore laterally equivalent to the glauconitic bed documented at Les Faïsses (Latil, 1995; Amédro, 2008 Gale et al., 2011; Reboulet et al., 2014). In the Helvetic Domain, some condensed authigenic deposits (phosphorite and glauconite) are reported for the Albian and some of these beds may be the lateral equivalent of the glauconitic beds of the Southeastern Subalpine Basin (Delamette, 1988). In the flooded platform of the Arc of Nice (Fig. 1C), glauconitic sandstone deposits are known in the l'Escarène area (e.g., Barale et al., 2015) and other places; they 
yielded upper Albian ammonites but need further biostratigraphic refinements. Along the south-eastern border of the Anglo-Paris Basin, the M. fallax Zone is marked by a distinctive, several meter-thick interval of glauconitic, bioturbated clays (Amédro and Madrion, 2014).

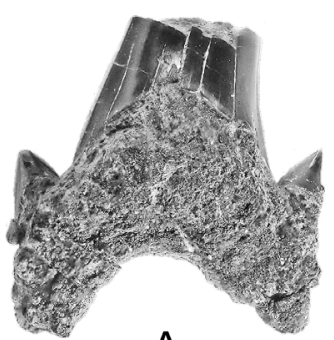

A

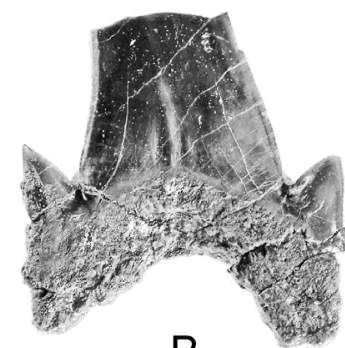

$\mathrm{B}$

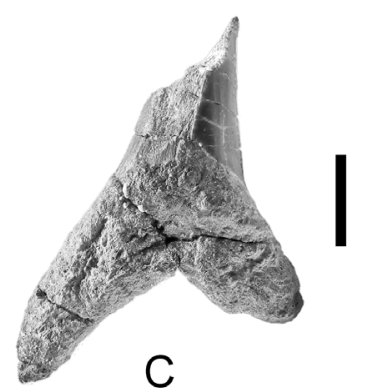

C

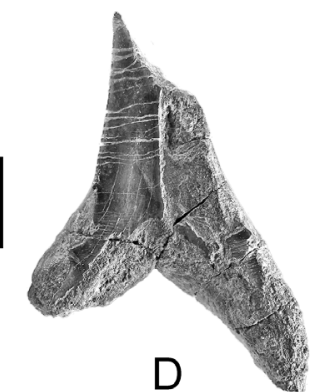

$\mathrm{D}$
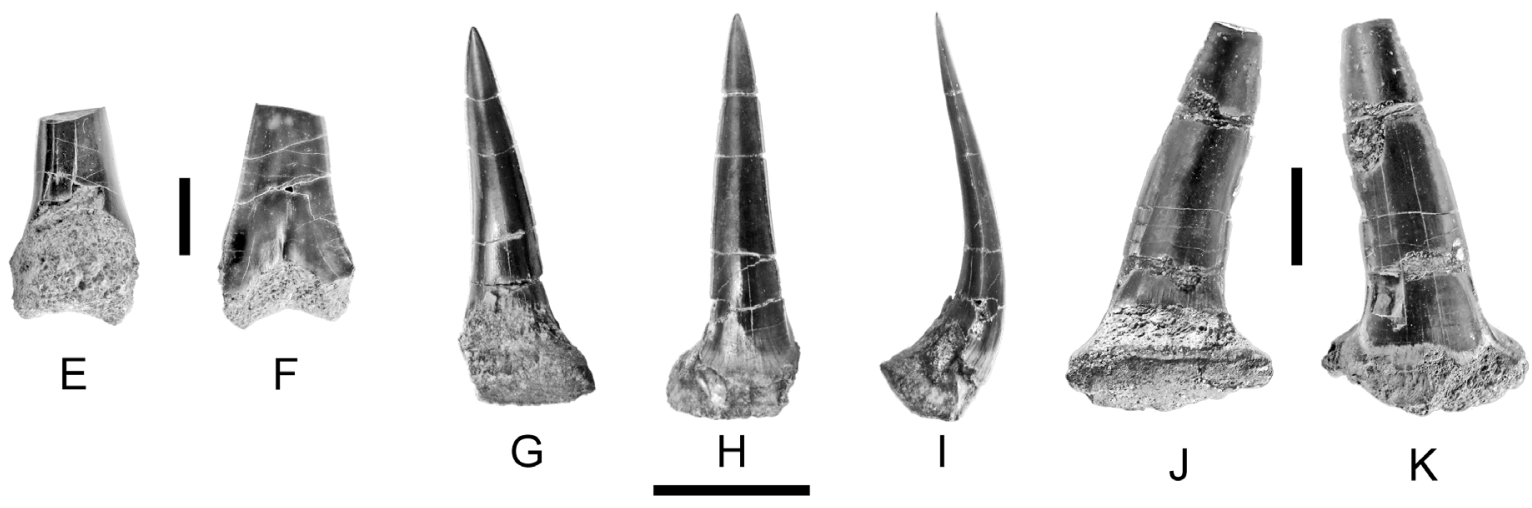

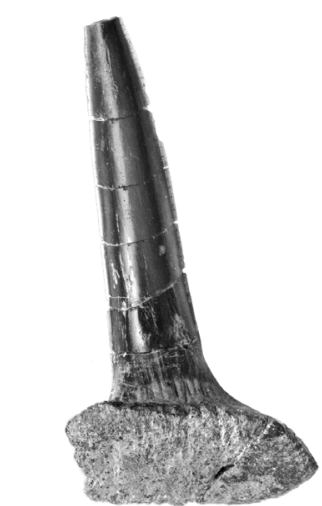

$\longrightarrow \mathrm{L}$

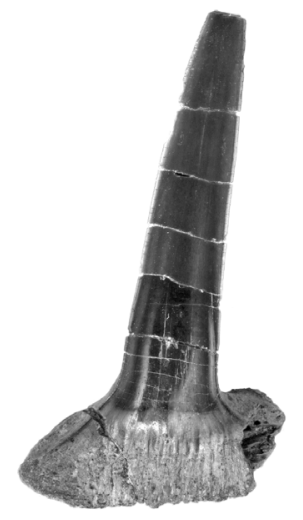

M

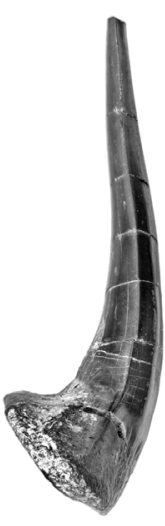

$\mathrm{N}$

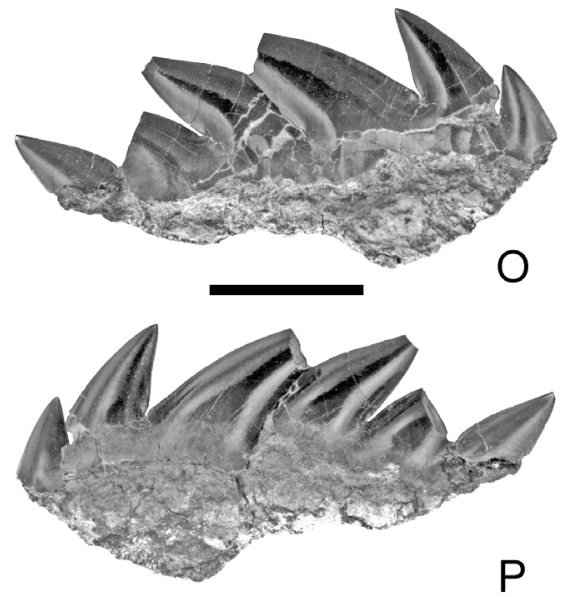

Figure 4. Chondrichthyans (sharks) collected from the fossiliferous glauconite-rich bed 98 and overlying bed 99 of Les Faïsses section. A-F. Lamniformes. A. Lingual view of Archaeolamna sp., lateral tooth (RNNGHP.04214-TA.049). B. Labial view of Archaeolamna sp., lateral tooth (RNNGHP.04214-TA.049). C. Lingual view of $c f$. Cretoxyrhina sp., anterolateral tooth (RNNGHP.04214-TA.064). D. Labial view of cf. Cretoxyrhina sp., anterolateral tooth (RNNGHP.04214-TA.064). E. Lingual view of Lamniformes indet. anterolateral tooth (RNNGHP.04214-TA.056). F. Labial view of Lamniformes indet. anterolateral tooth (RNNGHP.04214-TA.056). G-P. Hexanchiformes. G. Lingual view of Sphenodus sp. posterior tooth (RNNGHP.04214-TA.047). H. Labial view of Sphenodus sp. posterior tooth (RNNGHP.04214-TA.047). I. Profil view of Sphenodus sp. posterior tooth (RNNGHP.04214-TA.047). J. Lingual view of Sphenodus sp. anterior tooth 
(RNNGHP.04214-TA.035). K. Labial view of Sphenodus sp. anterior tooth (RNNGHP.04214TA.035). L. Lingual view of Sphenodus sp. anterolateral tooth (RNNGHP.04214-TA.057). M. Labial view of Sphenodus sp. anterolateral tooth (RNNGHP.04214-TA.057). N. Profil view of Sphenodus sp. anterolateral tooth (RNNGHP.04214-TA.057). O. Labial view of Notidanodon sp. lateral tooth (RNNGHP.04214-TA.042). P. Lingual view of Notidanodon sp. lateral tooth (RNNGHP.04214-TA.042). All scale bars equal $5 \mathrm{~mm}$ except $C-D$ and $J-K$ $(10 \mathrm{~mm})$.

\subsection{Microfacies and ammonite shell mineralogy}

Microscopic and macroscopic observations show that the fossiliferous glauconite-rich bed is a poorly sorted packstone with a micritic matrix, extremely rich in glauconite grains which occurs in sediment pores, or forming large surface coatings on the ammonite moulds, bivalves and brachiopods and as impregnation on fossil bones and fecal pellets. The clasts correspond to quartz (subangular, $\sim 20-25 \%, 50-100 \mu \mathrm{m}$ ), glauconite grains (subangular to rounded, $\sim 20$ $25 \% ; 50 \mu \mathrm{m}-2 \mathrm{~mm})$ and planktic foraminifera $(5-10 \%)$. The glauconite grains display a bimodal color distribution, suggesting two different origins and/or chemical compositions. There are no grading whatever considering all type of grains or only glauconite grains (See Supplementary Data 6 for illustrations of the glauconite-rich bed and microscopic observations.).

Ammonite aragonite layers composing the original shells are not preserved but were replaced by secondary diagenetic materials. Macroscopic and microscopic observations show that ammonite inner moulds are covered by three different layers, two green coatings forming the external and internal layers enfolding a white crystalline inner layer. Each layer is very thin and easily detached from one another. According to optical microscopy, XRD and SEM analyses, the white crystalline inner layer is made of equant or equigranular calcite and the two green coatings (external and internal ones) are made of fibrous glauconite with presence of pyrite and barite (Supplementary Data 7, 8 and 9). The XRD analysis of a green layer did not perfectly identify glauconite, likely due to imperfections due to glauconite swelling and/or potential interstratifications with other clayey minerals (e.g., smectite; Banerjee et al., 2016).

\subsection{Vertebrate remains}

\subsubsection{Ichthyofauna}

The fossiliferous glauconite-rich bed yielded several medium-size (3-4 $\mathrm{cm}$ in diameter) fish vertebrae (not shown) and teeth. All teeth suffered from strong sediment compaction and therefore, none of the teeth recovered are complete. Although most of the specimens are poorly preserved and undeterminable, some of them show identifiable characters. Chondrichthyans are represented by five shark species belonging to the orders Lamniformes (Fig. 4A-F) and Hexanchiformes (Fig. 4G-P). Three lamniform species were identified, each represented by a single tooth: Archaeolamna sp., cf. Cretoxyrhina sp. and Lamniformes indet. Among Hexanchiformes, three teeth and two fragmentary cusps are attributable to Sphenodus sp. representing the family Orthacodontidae Glikman, 1957. Although the genus Sphenodus ranges from the Sinemurian (Lower Jurassic) to the Danian (Paleocene), the specimens reported here represent the first record of the genus from the post-Valanginian Lower Cretaceous. The second hexanchiform taxon is represented by an incomplete tooth lacking the root attributed to Notidanodon sp. (family Hexanchidae Gray, 1851). Among the shark specimens reported here, hexanchiforms (particularly Sphenodus) dominate in terms of number of specimens. In addition, one tooth of the orthacodontid Sphenodus sp. (Fig. 4J-K) and one of the hexanchid Notidanodon sp. (Fig. 4O-P) were sampled from around the partial plesiosaur specimen described below. 
The shark assemblage comprises predator taxa (Lamniformes and Hexanchiformes) indicative of open marine settings of probably temperate waters (Notidanodon, Sphenodus). Some extant hexanchid sharks tend to prey actively on large marine vertebrates, including marine mammals (Ebert, 1991; Heithaus, 2001), but also commonly eat carrion (Ebert, 1991; Barnett et al., 2012). Sphenodus has also been interpreted as a potential scavenger since teeth of this taxon have been found in association with other marine tetrapod remains (Henning, 1914). Although the Sphenodus teeth reported here were found in close association with the plesiosaurian remains, the upper surface of these latter became deeply eroded before burial (see below), making it impossible to detect potential evidence for scavenging. Similarly, the dominance of hexanchid and orthacodontid remains reported here could be linked to the presence of a large vertebrate carcass, but given the degree of reworking and low sedimentation rates that most likely affected the sediment, the collected material might not be strictly contemporaneous.

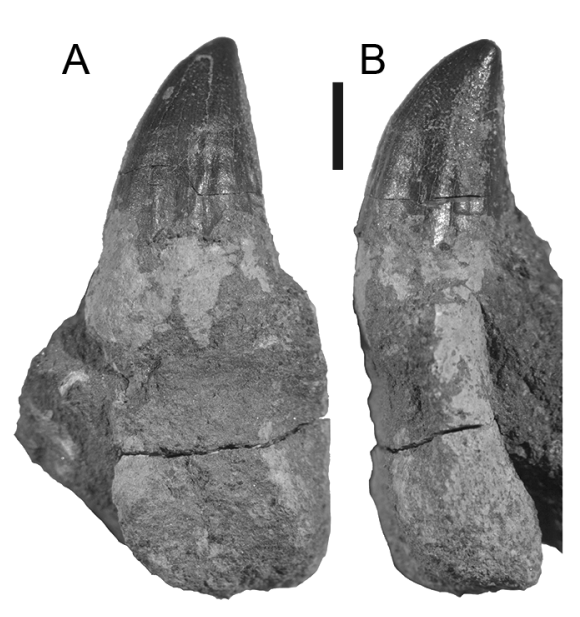

Figure 5. Ophtalmosauridae indet. tooth (RNNGHP.04214-TA.045) collected from the fossiliferous glauconite-rich bed 98 in Les Faïsses section. A. Labial view. B. Mesial view. C. Apical view. Scale bar equal $5 \mathrm{~mm}$.

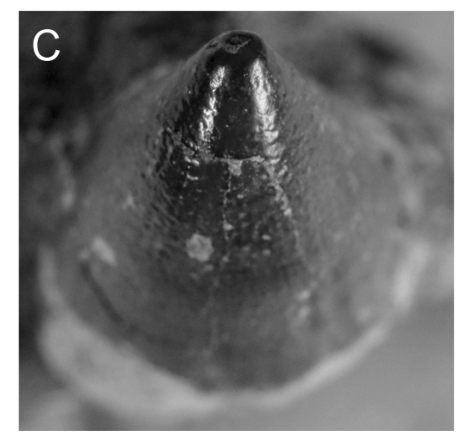

\subsubsection{Ichthyosauria}

The specimen RNNGHP.04214-TA.045 (Fig. 5) is an isolated tooth preserving the crown and root that was recovered from the fossiliferous glauconite-rich bed at Les Faïsses, about 10 $\mathrm{cm}$ above the horizon where the partial plesiosaurian skeleton was found. The crown preserves a conical shape whereas the root is slightly crushed due to preservation. The total height of the tooth is $26 \mathrm{~mm}$. In lateral view (Fig. 5B), the lingual margin of the crown is straight, and the labial margin is markedly convex with the apex directed lingually giving a strong lingually recurved profile to the crown. The tooth crown is devoid of mesiodistal carinae and its apex exhibits a small facet of occlusion (Fig. 5C). The enamel surface is irregular and can be divided into two areas according to its ornamentation pattern. From the apex down to half its height, the enamel surface bears small pockmarks giving a rugose aspect. On the basal half of the crown, about 15 longitudinal ridges are visible on the labial and lingual surfaces. The crown-root junction is continuous without a neck. The root is not well preserved but is complete and is subquadrangular in cross section. 


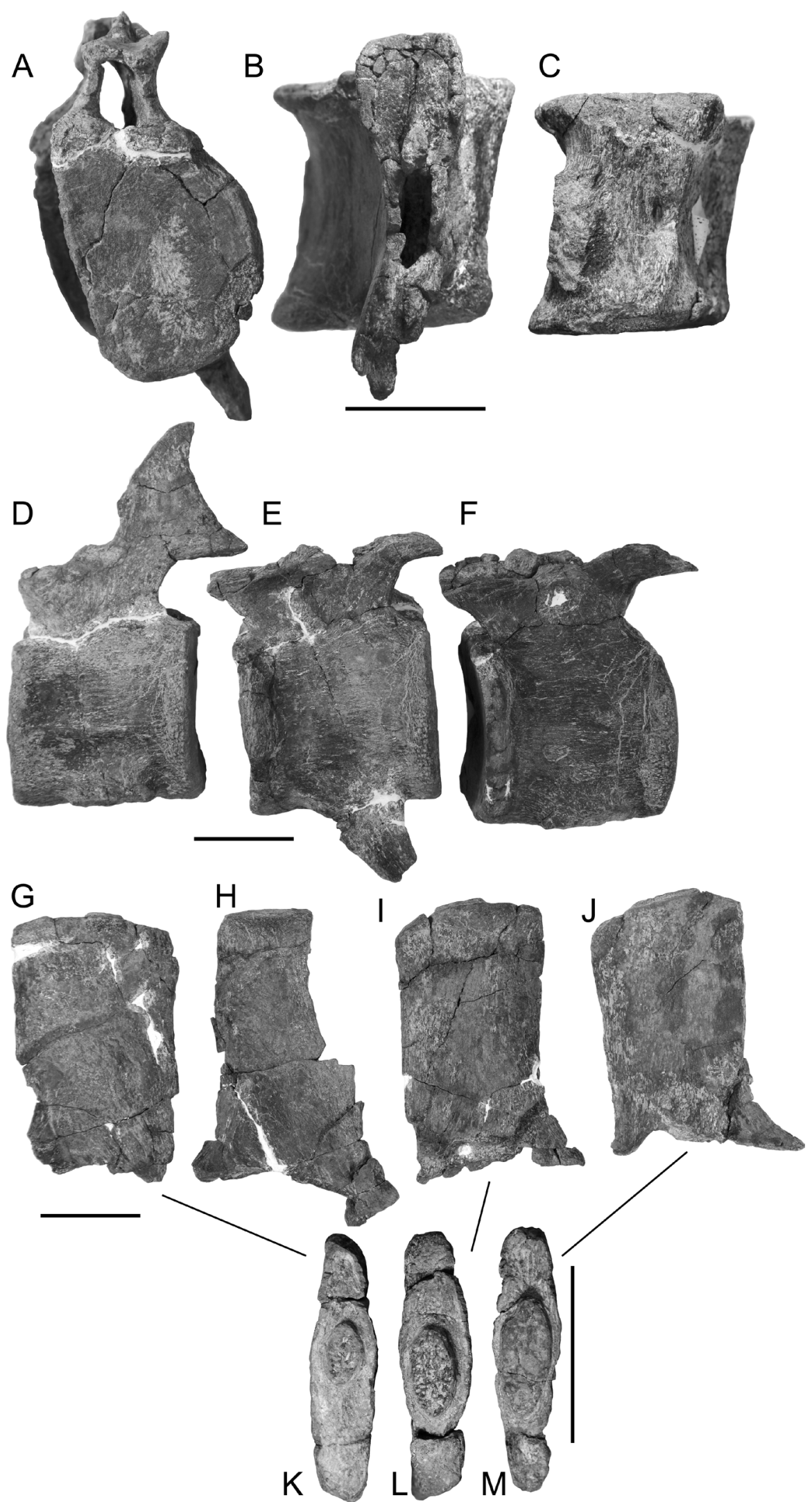

Figure 6. Elasmosaurid cervical vertebrae (RNNGHP.04214-TA.2015.1). A. Second preserved vertebra in anterior view. B. Third preserved vertebra in dorsal view. C. Third preserved vertebra in ventral view. D. First preserved vertebra in lateral view. E. Second preserved vertebra in lateral view. F. Third preserved vertebra in lateral view. G-J. Neural spines in left lateral view. K-M. Neural spines in dorsal view. Scale bars equal $50 \mathrm{~mm}$. 
As is typical for ichthyosaurs, the tooth crown (RNNGHP.04214-TA.045) represents less than half of the total tooth height (McGowan and Motani, 2003). The root is poorly preserved but is distinctly subquadrangular in cross section as is the case in ophthalmosaurids (Fischer et al., 2012). The crown surface shows fine pits in the apical area, a condition previously reported in other ophthalmosaurids such as 'Platypterygius' hercynicus (Fischer, 2012), Aegirosaurus (Fischer et al., 2011) and in 'Platypterygius' sp. (Fischer et al., 2014). The presence of longitudinal ridges on the basal enamel surface recalls the condition described by Fischer et al. (2012) for Acamponectes densus. Given the morphology described here, we tentatively identify this isolated tooth to an indeterminate ophthalmosaurid.

The specimen RNNGHP.04214-TA.061 is a set of four articulated amphicoelous vertebral centra excavated from a glauconite-rich bed in Les Parties ravine that is a lateral equivalent of the fossiliferous glauconite-rich bed documented at Les Faïsses (Fig. 1B). Each element is about $6 \mathrm{~cm}$ in height and consists of a poorly preserved centrum, which is strongly laterally deformed and preserves a poorly defined neurocentral suture. The lateral sides of the centra are too eroded to discern the apophyses connecting to the ribs. The vertebrae are too poorly preserved to allow a comparison with other known Albian taxa.

\subsubsection{Plesiosauria}

Elasmosauridae Cope 1869 (sensu Ketchum and Benson, 2010) gen. et. sp. indet.

- Material. Specimen RNNGHP.04214-TA.2015.1, a series of five cervical centra and detached neural arches and spines, a series of 26 caudal vertebrae plus two caudal neural spines without their centra, a few ribs, partial pelvic girdle, and partial hindlimbs. Field and preparation observations indicate that the surface of the bones of the plesiosaurian specimen originally exposed at the sediment-water interface became deeply abraded before burial (see section 5.4. for discussion; Fig. 3B). The poor preservation of the bones affected by this process rendered the preparation of the abraded surfaces and their detailed observation difficult.

- Ontogenetical stage. The femoral facets for epipodials bones are well defined and the neural arch sutures are closed, it is thus deduced that the specimen was an osteologically mature adult (sensu Brown, 1981) at time of death.

. Cervical vertebrae (Fig. 6). Five partial cervical vertebral centra with partial neural arches are preserved in connection. The assemblage of bones also includes one detached partial neural arch and five detached partial neural spines, but none of these can be positively associated with any of the vertebral centra. The right lateral parts of the centra were abraded possibly by winnowing or bioerosion prior to burial so that only approximately half of each centra are preserved. The remaining parts of the centra present anterior and posterior gently concave articular facets. Only one elongated nutritive foramen is preserved on each centrum, the second should have been most likely present originally on the abraded portion; the preserved foramen is not located in a marked depression as in the posterior cervical centra of Vegasaurus molyi (O'Gorman et al., 2015). There is a single-headed, ovoid in shape rib facet. Due to the poor preservation, the presence of a ventral notch or a ventral keel cannot be attested. A low lateral longitudinal ridge is present on the anteriormost preserved centrum, a feature typical of the anterior and middle parts of the cervical region of elasmosaurids (e.g., Vegasaurus molyi (O'Gorman et al., 2015); CM Zfr 115, previously Mauisaurus (Hiller et al., 2005) but see Hiller et al. (2017)), suggesting that the five centra belong to the posterior portion of the neck. The partial preservation makes the measurements difficult, but it seems that the centra are approximately as long as high, and broader than long and high (as usually found in the posterior cervicals of elasmosaurids (e.g., SGO.PV.6506 (Otero et al., 2014a, Albertonectes vanderveldei Kubo et al., 2012, and Lagenanectes richterae Sachs et al., 2017). 
Broad posterior cervical centra are present in some elasmosaurids (e.g., Elasmosaurus and Styxosaurus (Welles, 1952; Otero, 2016); Vegasaurus molyi (O’Gorman et al., 2015).

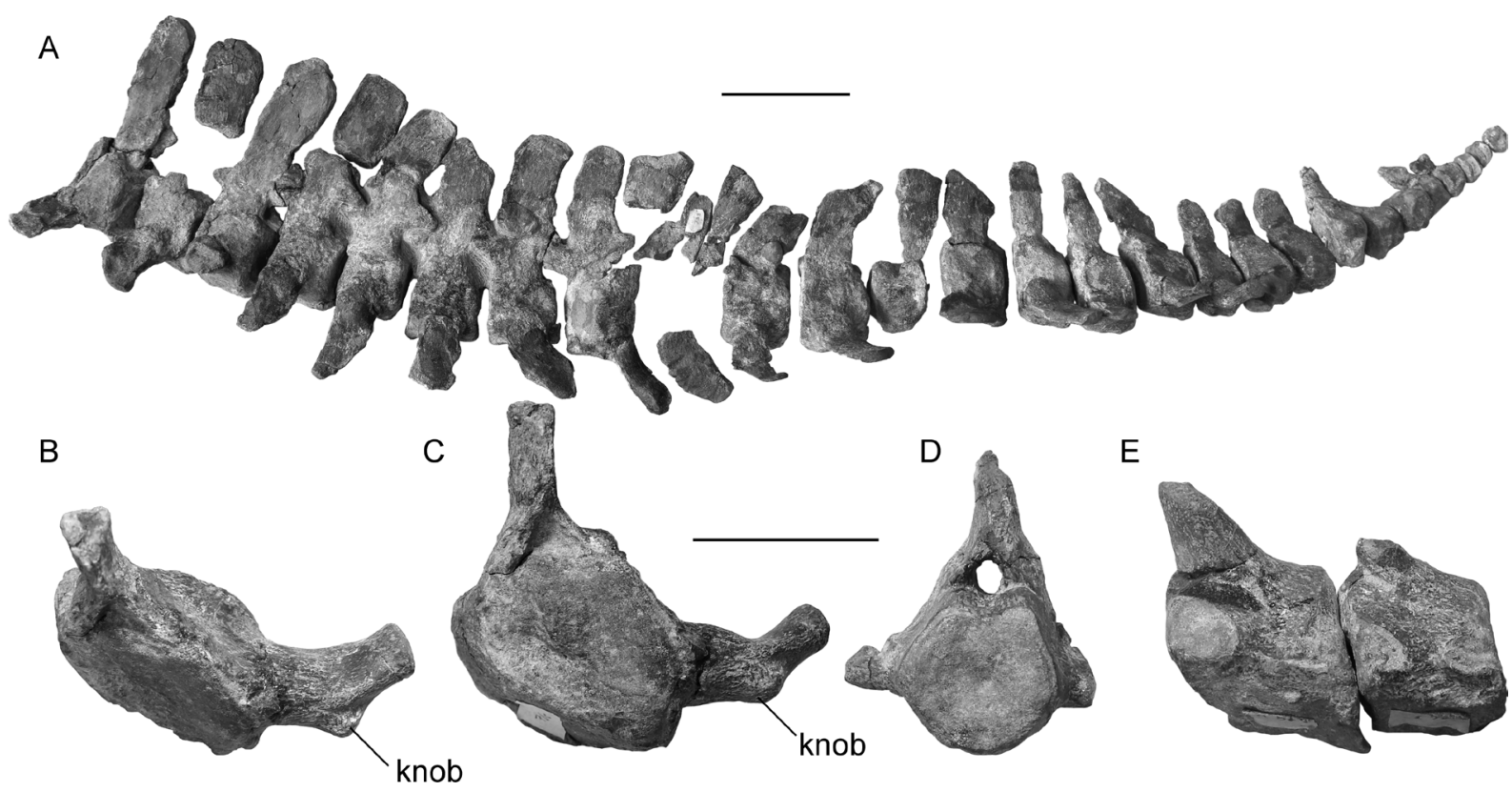

Figure 7. Elasmosaurid caudal vertebrae (RNNGHP.04214-TA.2015.1). A. Complete series in left lateral view; scale bar equals $100 \mathrm{~mm}$. B. $17^{\text {th }}$ preserved vertebra in anterodorsal view. C. $17^{\text {th }}$ preserved vertebra in anterior view. D. $21^{\text {st }}$ preserved vertebra in posterior view. $E$. $22^{\text {nd }}$ and $23^{\text {rd }}$ preserved vertebrae in ventral view. B-E. Scale bar equals $50 \mathrm{~mm}$.

The pre- and postzygapophyses are transversely clearly narrower than the centra. Right and left prezygapophyses are not divided medially along their ventral edges but sutured to form a trough that is ' $U$ '-shaped in anterior view as in many elasmosaurids (e.g., Kubo et al., 2012; Sato, 2003; Sato et al., 2006; Vincent et al., 2013; Welles, 1943; Sachs and Kear, 2017; Hiller et al., 2005) and project just beyond the level of the centrum anterior articular surface. It is not possible to determine whether the postzygapophyses are conjoined along their entire extension due to the poor state of preservation of this structure, however, a median contact between the left and right postzygapophyses is at least present anteriorly.

The neural spines are plate-like, dorsally directed and slightly inclined straight posterodorsally, with a groove on their posterior edges as in Albertonectes vanderveldei (Kubo et al., 2012). Three of them preserved a small rounded projection on the top of the dorsal extremity (Fig. $6 \mathrm{~K}-\mathrm{M}$ ). These projections could correspond to areas of ligament attachment. To our knowledge, these structures have never been observed in other plesiosaurian specimen. Using an extant phylogenetic bracket, Nagesan (2017) reconstructed the supraspinous ligament (a ligament that runs dorsally along the cervical vertebral column in most vertebrates; Stevens and Parrish, 1999) to be attached along the dorsal margins of each of the neural spines of the cervical vertebrae of Nichollssaura borealis. It is thus hypothesized that the small rounded projections correspond to the same areas of supraspinous ligament attachment in RNNGHP.04214-TA.2015.1.

. Caudal vertebrae (Fig. 7). A series of 26 caudal vertebral centra preserving partial neural arches and ribs (except for last ones) plus one neural spine and rib preserved at the level of a missing centrum are preserved. The total count is of 27 caudal vertebrae; however, some anterior caudals are probably missing. As for the cervicals, the right side of the centra was highly abraded before burial as well as most of the ventral part except in the last vertebral centra. The anterior articular facets also present a slightly eroded surface. Moreover, the 
vertebrae are slightly deformed by compaction during fossilization. The suture between centra and ribs are closed. The centra are short. The anterior and middle caudal centra seem to be well rounded but the posteriormost ones become more hexagonal in cross-section. The edges of the articular facets are blunt from the $15^{\text {th }}$ one (Fig 7B) and may be the result of natural wear and tear, related to tail movements during the animal's life. Caudal ribs facets are located at the midheight of the centrum. Areas where possible chevron facet could have been present are not preserved in the anterior and middle caudals. However, the chevron facets are preserved in the posteriormost caudals and are located equally on anterior and posterior edges of the centrum. The anterior caudal spines are dorsally directed but from the $16^{\text {th }}$ caudal the spine orientations change and are curved anteriorly. From the $19^{\text {th }}$ caudal, the spines are damaged, and the spine orientations are unclear. A change in the neural spine orientation is also observable in caudals of Albertonectes vanderveldei (Kubo et al., 2012).

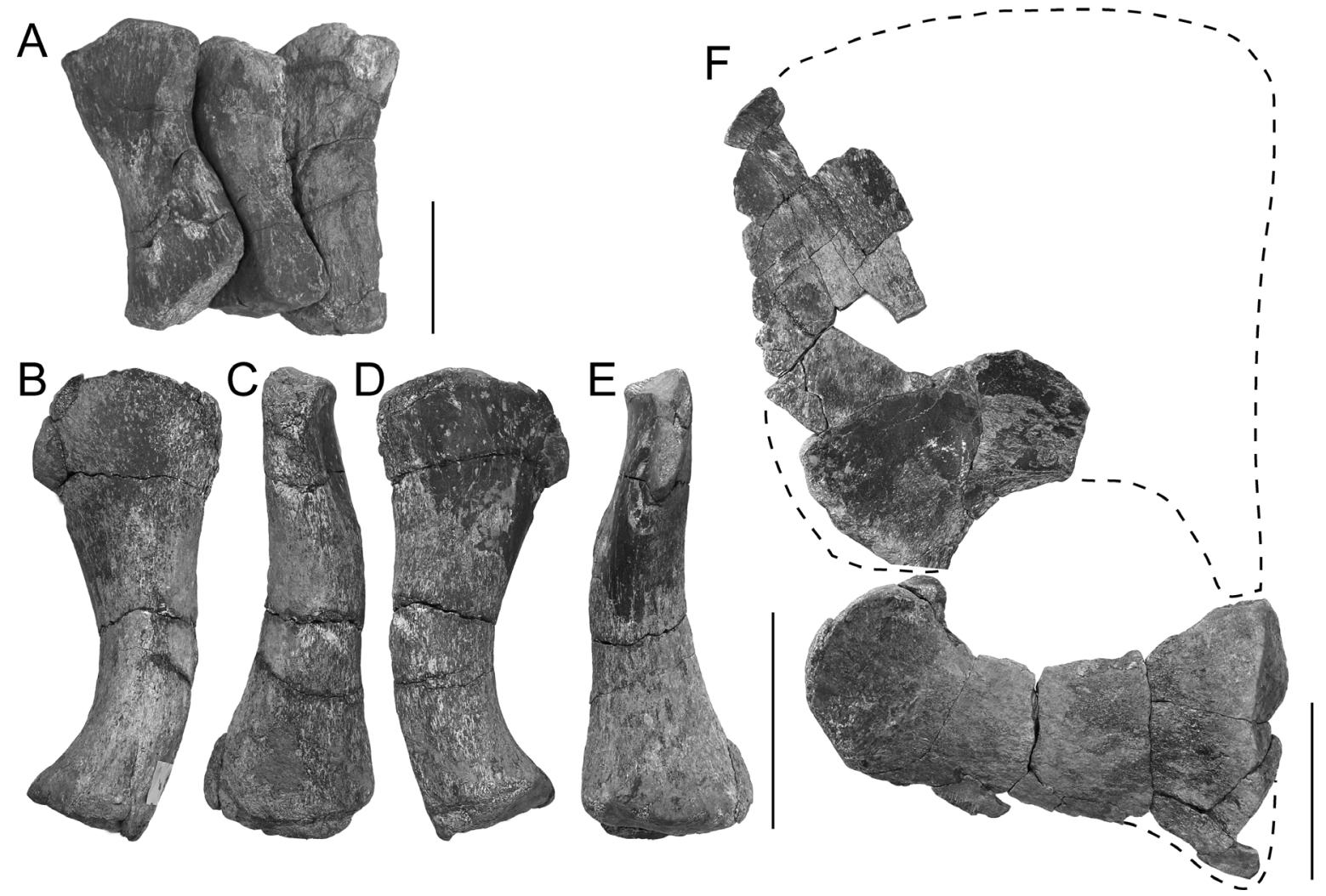

Figure 8. Elasmosaurid girdle (RNNGHP.04214-TA.2015.1). A Right sacral ribs in dorsal view; scale bars equal $50 \mathrm{~mm}$. B. Left ilium in lateral view. C. Left ilium in proximal view. $D$. Left ilium in anterior view. E. Left ilium in posterior view. F. Left pelvic girdle. B-F. Scale bars equal $100 \mathrm{~mm}$.

- Ribs. One partial cervical rib is preserved attached to its centrum but do not allow the observation of its shape and possible anterior-posterior expansion due to its poor state of preservation (Fig. 6E). Five sacral ribs are preserved. They are robust and anteroposteriorly compressed. All sacral ribs are about equal in length (Fig. 8A). They are slightly enlarged at both extremities. The proximal end bears two angled facets for articulation with the neural arch and centrum, a smaller dorsal part and a large ventral one. In all ribs a ridge extends along craniodorsal edges. Three sacral ribs were found close to each other and most likely correspond to a group of successive ribs as the anterior surface of the distal end of each sacral rib is a good fit against the posterior surface of the following one. The caudal ribs are poorly preserved. They seem subrectangular to sub-triangular in dorsal view and are dorsoventrally 
flattened. The $11^{\text {th }}, 16^{\text {th }}$ and $17^{\text {th }}$ caudal ribs enlarge anteroposteriorly at midlength, a character that seem natural and not the result of taphonomic processes (but this possibility cannot be excluded). The $17^{\text {th }}$ caudal rib is the best preserved. It is oriented horizontally and laterally curved dorsally. It enlarges distally to form a blunt tear-drop end. The anteroventral margin of the $17^{\text {th }}$ caudal rib presents a prominent knob that is not present in other caudal ribs when observable (Fig. 7C, D).

. Ilium. The ilium (Fig. 8B-E) is a stout rod-like bone with a well-flattened expanded (fanshaped) distal end (as observed in Thalassomedon hanningtoni Welles, 1943 and Terminonatator ponteixensis Sato, 2003), but appears wider than in Futabasaurus suzukii Sato et al., 2006 and Vegasaurus molyi O'Gorman et al., 2015. The expansion is almost symmetrical. The proximal end is abraded so that the presence of several articular facets cannot be attested. The ilium is strongly twisted; the proximal end is rotated approximately 90 degrees relative to the distal end. The midpart of the iliac shaft has an oval cross-section. The ilium shows a curved shape, lacking the distinct knee, a feature also observed in Morenosaurus stocki (Welles, 1952), Futabasaurus suzukii (Sato et al., 2006) and Terminonatator ponteixensis (Sato, 2003).

. Pubis (Fig. 8F). Only the lateral edges and articular facets of the left pubis are preserved. The bone is very thin, except near the articular facets area where it thickens considerably. The ischial and acetabular facets are abraded and information about their length and orientation are unavailable. The posterior margin of the pubis is concave, forming the anterior margin of the ischiopubic foramen. The lateral border is almost straight.

- Ischium. The left ischium is almost complete (Fig. 8F), however, its most posterior portion is not preserved: from the articulation with the ilium and femur until the last third of its width medially, its posterior edge is preserved, whereas the bone in the last postero-medial portion shrinks considerably without preserving the most posterior edge. The missing part was thus most likely not extended. The ischium therefore presented an anteroposterior length most likely smaller than its mesolateral width as in some juvenile individual (e.g., SGO.PV.260, a Maastrichtian Aristonectinae indet.; Otero et al., 2012; NZGS CD429, Wiffen and Moisley, 1986). Adult individual usually present ischia longer than wide, except in Futabasaurus suzukii (Sato et al., 2006), which present a left ischium as long as wide. The thickest zone corresponds to the acetabulum. The acetabular portion is oval and convex, the pubic facet is smaller. The acetabular and pubic facets form an angle of approximately $100^{\circ}$. The symphyseal surface is thickened.

. Hindlimbs (Fig. 9). The left femur is almost completely preserved, as well as a very fragmentary distal portion of the right one. The proximal end of the left femur is incomplete making it impossible to assess its morphology. The femoral shaft is straight. The femur starts to expand anteroposteriorly just posterior to the articular end, with the postaxial side exhibiting more rapid expansion than the preaxial side. The epipodial facet for the tibia is flat whereas the facet for the fibula is convex. There are no supernumerary facets.

Both the tibia and fibula of the two hindlimbs have been preserved (Fig. 9). The tibia is a subrectangular element and is wider than long. The tibia's proximal contact with the femur is gently convex and merges with the straight preaxial margin. The postaxial edge of the tibia is thick (not dorsoventrally flattened as in Libonectes morgani (SMNK-PAL 3978, previously $L$. atlasense Buchy, 2005), see Allemand et al. 2017) and embayed where it encloses a narrow epipodial foramen. The tibia has a small facet for the intermedium on its distal postaxial border and a larger one for the centrale. The fibula displays a semi-lunate shape with a convex postaxial side and a concave preaxial one that enclosed the epipodial foramen. The fibula is as long as wide and has two distinct facets on its distal margin for the intermedium and fibulare. The epipodial foramen is closed distally by contact between the epipodials as in Futabasaurus 
suzukii. The tibia is dorsoventrally compressed on its preaxial side, whereas the fibula is dorsoventrally compressed on its postaxial side.

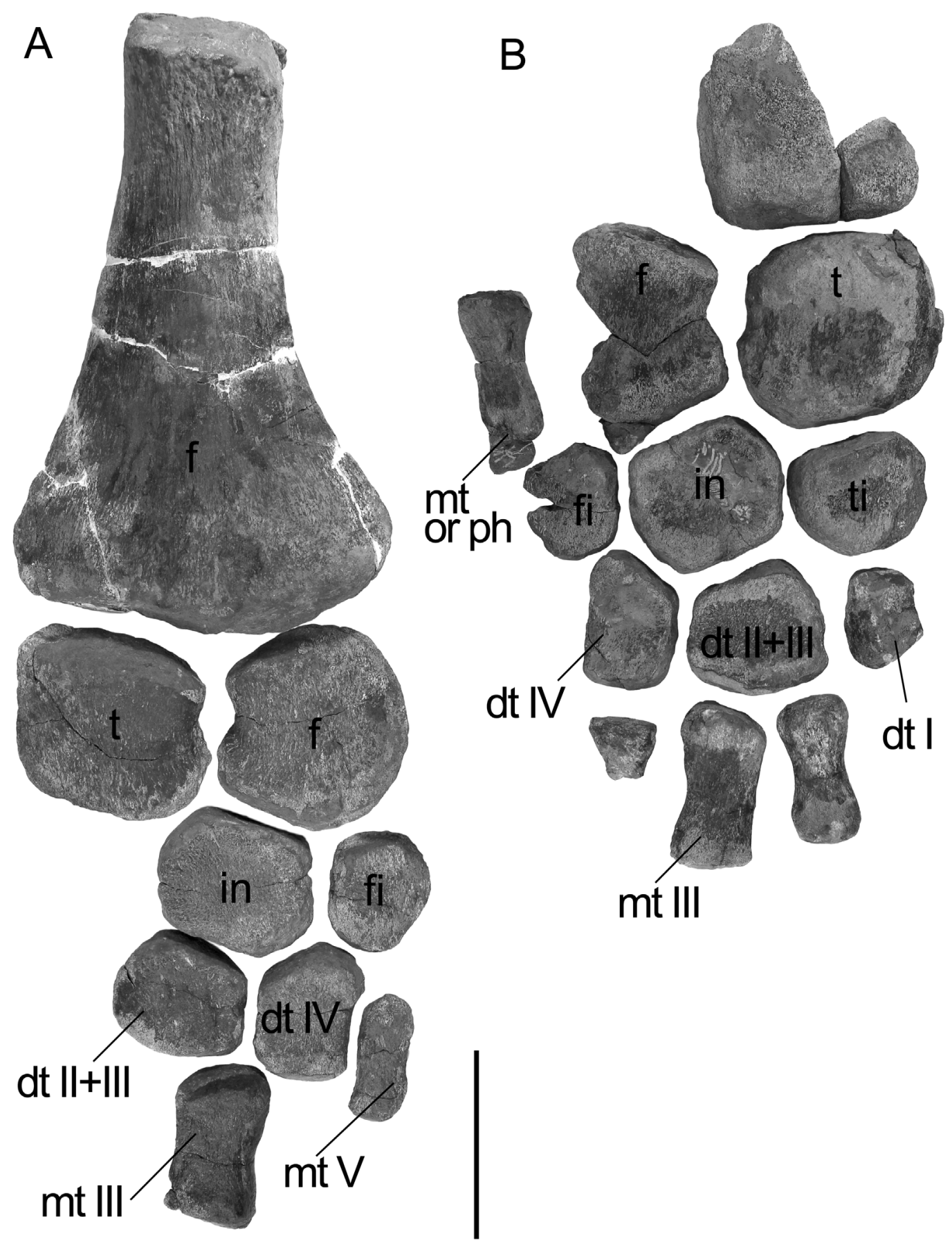

Figure 9. Elasmosaurid hindlimbs (RNNGHP.04214-TA.2015.1). A. Right hindlimb in ventral view. B. Left hindlimb in ventral view. Scale bar equals $100 \mathrm{~mm}$.

The intermedium is a distorted hexagon with six distinct facets (Fig. 9). The facet for the tibia is the smallest. The facets for the fibula and distal tarsal (dt) $2 \& 3$ are the largest. A reduced tibial facet of the intermedium is shared with Aristonectes, Aphrosaurus furlongi and Terminonatator ponteixensis but differs from that observed in Mauisaurus (Welles, 1943; Sato, 2003; Hiller et al., 2005) There is a pit penetrating the center of the left intermedium, a 
feature also reported for Terminonatator ponteixensis (Sato, 2003). The fibulare is rhomboid in dorsal view but incomplete in both sides. It bears one proximal and one distal facet. The centrale is partially preserved in the right paddle only and presents a pit penetrating its center. A poorly preserved dt 1 is present on the right paddle. The dt $2 \& 3$ is hexagonal in shape with the largest facet for the intermedium proximally. It is pierced by a pit situated approximately in its center. The dt 4 is quadrangular and proximodistally elongated and bears five distinct facets for articulation with surrounding bones. It lies almost entirely in the metatarsal row. Metatarsal II is preserved on the right paddle only. Metatarsal III is preserved on both paddles. The shape of metatarsal $\mathrm{V}$ fits against the corresponding facet of dt 4 .

Several phalanges are preserved but not in anatomical connection. They are unremarkable: proximodistally elongate and constricted at their midsection to form an hourglass shape.

- Gastroliths (Fig. 10). Five quartz and black chert pebbles were recovered within and around the specimen. They all are rounded and have smooth surfaces; their mean diameters range from $0.7 \mathrm{~mm}$ to $30 \mathrm{~mm}$. Isolated pebbles are unknown from elsewhere in the bed and thus most likely correspond to gastroliths.

Figure 10. Chert and quartz pebbles found associated with the plesiosaurian remains (RNNGHP.04214-TA.2015.1; see also Fig. 3) and likely corresponding to gastroliths. Scale bar equals $10 \mathrm{~mm}$.

\subsection{Taphonomical and paleoenvironemental results}

The fossil remains described herein from an upper Albian glauconite bed show several notable compositional and preservational features that provide valuable insights into their depositional setting.

The mostly articulated nature of the portion of plesiosaurian specimen (RNNGHP.04214TA.2015.1) suggests it has been only slightly displaced by the action of scavengers or bottom currents before burial. It can thus be reasonably presumed that the specimen was relatively complete before it weathered out. Careful examination of the sedimentary rocks-fossil interface during field excavation and subsequent preparation in the lab revealed that the surface of the bones of the plesiosaurian specimen originally exposed at the sediment-water interface became deeply abraded before burial (Fig. 3B), possibly as the result of bioerosion or strong winnowing. The strongly asymmetrical shape of the largest cervical and caudal centra in anterior or posterior view (Fig. 6) indicates that abrasion has removed approximately one- to two-thirds of their original thickness. In cross-section, the stratigraphically uppermost, poorly preserved parts of the bones show a distinctive greenish color that may extend 
downward from a few millimeters to up to several centimeters, while the lowermost surfaces are generally very dark and excellently preserved. These upper surfaces seem generally very flat, clear-cut and parallel to the stratigraphic bedding, and lack distinctive marks of scavenging, such as scratches, grooves or bite marks, or invertebrate macroborings. These surfaces may thus have been formed through the grazing of the bone by invertebrates such as gastropods or echinoids, or through repeated and dense microborings made by algae, fungi or bacteria (Kaim et al., 2008). Alternatively, fossil abrasion and low sedimentation rates might have also been produced by strong bottom currents. The occurrence of persistent bottom currents during the deposition of the whole bed seems at odds with the abundance of small planktic foraminifera and calcareous nannofossils observed in thin-sections and smear slides. Nevertheless, strong currents may have only periodically swept the sediment-water interface, allowing the settling and preservation of the fine fraction during phases of reduced current activity, as much as recorded in Quaternary contourite sequences (Tallobre et al., 2019). In any case, very reduced sedimentation rates/condensation are also suggested by the spectacular density of ammonite shells and other cephalopod remains, such as beaks (rhyncholites) and belemnite rostra, which are otherwise very rare in the surrounding beds of the Marnes Bleues Formation.

Microfacies and ammonites provide further constraints on the depositional and diagenetic conditions. As noted in section 4.2., the fossiliferous bed is notable for the pervasive occurrence of glauconite, which is mainly present as glauconitic grains - that could represent lobate faecal pellets - and coatings on fossils. Coatings are particularly spectacular on ammonite moulds, covering the whole surface even in the largest specimens, which rule out an allochthonous origin of glauconite. The formation of authigenic glauconite, generally associated with very low sedimentation rates, results from oxygenation level oscillations, indicating suboxic to anoxic conditions close to the sediment-water interface (Odin and Matter, 1981; Bréhéret, 1991; Neumann et al., 2011; Gorski et al., 2013). Apart from abiogenic grains such as feldspar, quartz and biotite, the preferred substrate for glauconitization are faecal pellets and bioclasts of various origins (mostly foraminifera, but also echinoderms and mollusks; compare Banerjee et al., 2016). The leading hypothesis is that glauconite forms as a consequence of bacteria-mediated degradation of locally higher organicrich contents.

The ammonite taphonomical history is following the same model. Regular ammonoid shells consist in three aragonite layers, two prismatic layers enclosing a nacreous layer (Kulicki et al., 2015). In our case, the ammonite internal moulds are covered by three layers of material differing from the original shell and hence resulting from a diagenetic transformation. Although likely simplistic, the model proposed here is a transformation of the nacreous aragonitic layer into the equant calcite layer similarly to observation in Janiszewska et al. (2018). Due to the low-oxygen conditions and in presence of organic matter from the shell internal chambers and periostracum (i.e., external organic coating layer of the shell; Lowenstam and Weiner, 1989), both external and internal prismatic aragonite layers were transformed into fibrous glauconitic coatings. Alternatively, the equant calcite layer result from the transformation of all three original aragonitic layers whereas the external and internal glauconite coatings are related to organic matter decay and authigenic growth from the periostracum and the internal chambers. Further observations and sampling would be necessary to confirm one or the other proposed model.

Altogether, the observations listed above suggest that the deposition of the fossiliferous glauconite-rich bed 98 took place under fluctuating but generally low oxygen contents, with residual organic matter in pellets and some skeletal or shell remains acting as a substrate for glauconite authigenesis. The sedimentation rate was very low with episode of accumulation without energy at the origin of the good preservation of ammonite geometry and delicate 
features (e.g., spines); or the sedimentation rate was fluctuating from low energy to halts associated with episode of winnowing, erosion, reworking and bypass.

\section{Discussion}

\subsection{Comparison and affinities of the plesiosaurian remains}

The presence in RNNGHP.04214-TA.2015.1 of transversely concave cervical prezygapophyses that are not widely separated on the midline is uniquely shared with elasmosaurids, cryptoclidids, and some polycotylids and leptocleidids (Benson et al., 2013). Moreover, the shaft of the ilium shows a characteristic curved shape, a feature observed in cryptoclidids, some elasmosaurids and polycotylids (e.g., Andrews, 1910; Albright et al., 2007; Evans, 2012). However, RNNGHP.04214-TA.2015.1 differs from polycotylids that possess strongly elongate backwards ischia (Carpenter, 1996). In addition, the posterior margins of the cervical neural spines are grooved contra that reported for cryptoclidids (except Muraenosaurus; Ketchum and Benson, 2010).

RNNGHP.04214-TA.2015.1 displays a number of typical elasmosaurid traits listed by Brown (1993), Ketchum and Benson (2010), Otero et al. (2012) and Otero (2016) including anterior cervical centra with nearly circular shape in articular view, slightly amphicoelous; successive anterior cervical centra acquiring a longitudinal lateral ridge; pre- and postzygapophyses on the cervicals partially meeting in the midlines that are narrower than the centra; neural arch markedly narrower than centrum, especially in cervical vertebrae; singleheaded cervical ribs; epipodials broader than long, and a shift of the fifth metacarpal into the distal carpal row.

RNNGHP.04214-TA.2015.1 can be compared to other elasmosaurid specimens only insofar as they have posterior cervicals, caudals, pelvic girdle and hindlimb bones in common. Comparisons are therefore limited by the poor knowledge of the postcranial morphology of many elasmosaurid species (e.g., Aristonectes parvidens Cabrera, 1941 (see Gasparini et al., 2003); the holotype of Tuarangisaurus keyesi Wiffen and Moisley, 1986; Zarafasaura oceanis Vincent et al., 2011; Alexandronectes zealandiensis Otero et al., 2016; Leivanectes bernardoi Paramo-Fonseca et al., 2019). Moreover, some elasmosaurid taxa known only from postcranial elements do not preserve elements shared with our specimen, i.e. comparisons with other Albian taxa (such as Wapuskanectes betsynichollsae Druckenmiller and Russell, 2006 and Eromangasaurus carinognathus Kear, 2005 respectively from Canada and Australia) are thus impossible. In addition, some taxa have been defined on juvenile specimens (e.g., Fresnosaurus drescheri Welles, 1943; Spitrasaurus Knutsen et al., 2012) and a number of differences or similarities between our specimen and these taxa could be interpreted as related to ontogenetic variations.

RNNGHP.04214-TA.2015.1 differs from all known elasmosaurid taxa for which comparisons are possible. All centra are longer than they are high in the Maastrichtian taxa Cardiocorax mukulu Araújo et al., 2015, contra that observed in RNNGHP.04214-TA.2015.1. RNNGHP.04214-TA.2015.1 differs from the Campanian taxon Elasmosaurus that possesses lateral longitudinal ridges on all cervical centra (Welles, 1952) and, on the contrary, differs from the Aptian-Albian taxa Opallionectes andamookaensis Kear 2006, the Santonian taxa Futabasaurus suzukii Sato et al., 2006, and the Maastrichtian Nakonanectes bradti Serratos et al., 2017, which have no lateral longitudinal ridge in any of their cervical centra. RNNGHP.04214-TA.2015.1 presents a straight to posterodorsally slightly inclined posterior cervical neural spine contra that reported for Futabasaurus suzukii, the Campanian taxa Terminonatator ponteixensis Sato, 2003 and the Maastrichtian species Aristonectes quiriquinensis Otero et al., 2014b, which possess neural spines angled anteriorly. It does not present any anterior projection (as in Cardiocorax mukulu) or posterior projection (as seen in the Aptian taxa Callawayasaurus colombiensis (Welles, 1962)) on the cervical neural spine. 
The prezygapophyses project well beyond the articular faces of the centra at around twothirds of their articular surface length in the posteriormost cervical vertebrae in the Turonian elasmosaurid Libonectes morgana (Sachs and Kear, 2015) contra that observed in RNNGHP.04214-TA.2015.1. RNNGHP.04214-TA.2015.1 does not show the octagonal outline of the anterior caudal centra considered as diagnostic of the genus Aristonectes (Otero and O'Gorman, 2013; Otero et al., 2014a). The Maastrichtian taxa Vegasaurus molyi O'Gorman et al., 2015 and the specimen CM Zfr 145 (Hiller and Mannering, 2005), as well as the Campanian specimen DM R1529 of Mauisaurus (Hiller et al., 2005) are distinguishable by an ilium with a marked angle. Moreover, the dorsal facet of the ilium of Vegasaurus molyi is not fan-shaped. The Campanian-Maastrichtian taxa Kawanectes lafquenianum has an unexpanded dorsal end of the ilium (O'Gorman, 2016a). The diagnoses of Fresnosaurus drescheri also indicate an ilium distally unexpanded, with anterior and posterior knob in the ventral area of the sacral facet and the posterior margin of the middle shaft, features that are absent in RNNGHP.04214-TA.2015.1. The iliac shaft of the Hauterivian Lagenanectes richterae is less twisted and more gracile than that of the specimen here described. Callawayasaurus colombiensis, Futabasaurus suzukii, Hydrotherosaurus alexandrae, Mauisaurus (Hiller et al., 2005), the Maastrichtian taxa Aphrosaurus furlongi Welles, 1943, the Cenomanian taxa Thalassomedon hanningtoni Welles, 1943, all differ from RNNGHP.04214-TA.2015.1 by the presence of a convex knee on the anterior border near the distal end of the femur instead of a concave anterior border extending to the distal articulation observed in our specimen. The anterior margin of the femora of the Berriasian taxa Gronausaurus Hampe, 2013 (an Elasmosauridae following Benson and Druckenmiller, 2014) is nearly straight and thus differs from that of RNNGHP.04214-TA.2015.1. The femur shaft flares distally and forms three distinct facets in Cardiocorax mukulu contra that observed in RNNGHP.04214-TA.2015.1. The femur possesses tibial and fibular facets that are almost in the same plane in CM Zfr 145 (Hiller and Mannering, 2005), differing from RNNGHP.04214TA.2015.1. Styxosaurus sp. (AMNH 1495: formerly holotype of Hydralmosaurus; Otero et al., 2016), Thalassomedon hanningtoni, and Aphrosaurus furlongi are all differentiated from RNNGHP.04214-TA.2015.1 by the absence of an epipodial foramen. Moreover, in Styxosaurus sp. (AMNH 1495), there is a straight postaxial margin of the tibia and a straight preaxial margin of the fibula and a deeply concave postaxial margin of the fibula (Otero et al., 2016). The Maastrichtian taxa Morenosaurus stocki Welles, 1943 and Kaiwhekea katiki Cruickshank and Fordyce, 2002 have a concave preaxial border of the tibia. Terminonatator ponteixensis Sato, 2003 differs by having a much reduced epipodial foramen, a convex preaxial margin of the radius and a sesamoid bone related only to the fibulare (Otero, 2016). The indeterminated elasmosaurid SGO.PV.6506 (Otero et al., 2014a), Kaiwhekea katiki, and the Campanian taxa Albertonectes vanderveldei Kubo et al., 2012 are dissimilar to RNNGHP.04214-TA.2015.1 as the former presents a fibula having a rectangular contour, and the two latters a straight postaxial side of fibula, while the fibula of RNNGHP.04214TA.2015.1 displays a semi-lunate shape.

The extreme shortness of the ischium is a feature that RNNGHP.04214-TA.2015.1 shares with some specimens of elasmosaurids that present an osteologically immature external morphology, but that has never been reported in osteologically mature individuals of this group. O'Gorman (2016b) states that there is a progressive extension of the posterior ramus of the ischium of elasmosaurids during ontogeny. A short ischium has been reported in Fresnosaurus drescheri (O'Gorman, 2016b), the New-Zealander specimen NZGS CD429 (Wiffen and Moisley, 1986), and in some other elasmosaurids (e.g., MML PV 5, MGUAN PA120, and SGO.PV.260, three Aristonectinae indet. from Argentina, Angola and Chile respectively; O'Gorman et al., 2014; Otero et al., 2012; Araújo et al., 2015), but all are considered as juveniles having an osteologically immature external morphology. No mature 
specimen of Fresnosaurus drescheri is known and the ischium is not preserved in the type specimen (considered as an adult by Wiffen and Moisley, 1986) of Tuarangisaurus keyesi. It is thus not possible to verify whether these taxa retain this feature at what appears to be an 'adult' stage considering the external morphology. However, the histological analyses performed by Araújo et al. (2015) on the Angolan specimen MGUAN PA120 indicate it is a paedomorphic adult and suggest that it also could be the case in the Argentine and NewZealander specimens MML PV 5 and NZGS CD429. RNNGHP.04214-TA.2015.1 being an 'adult' (sensu Brown, 1981), the short ischium could correspond to a peadomorphic feature and could represent a diagnostic character. Several authors proposed that the aristonectine elasmosaurids retain morphological features related to the juvenile condition (Araújo et al., 2015; O'Gorman et al., 2014). However, it must be noted that RNNGHP.04214-TA.2015.1 does not present any other paedomorphic features (e.g., the unfaceted distal propodials and the non-fusion of the neural arches with the centra, recognized in the paedomorphic Angolan specimens by Araújo et al. (2015)). RNNGHP.04214-TA.2015.1 is thus dissimilar from the Angolan, New Zealand and Patagonian material and does not belong to the widespread paedomorphic unnamed taxon hypothesized by Araújo et al. (2015).

RNNGHP.04214-TA.2015.1 can be referred to the Elasmosauridae and seems to differ from all taxa of this family. The short posterior projection of the ischium in RNNGHP.04214TA.2015.1, which could correspond to a paedomorphic feature, points out possible aristonectine affinities. However, the diagnosis of Aristonectinae O'Keefe and Street, 2009 (sensu Otero, Soto-Acuna, and Rubilar-Rogers, 2012) as well as the diagnosis of Styxosaurinae Otero, 2016 do not include helpful characters for the identification of RNNGHP.04214-TA.2015.1; moreover, as highlighted by O'Gorman (2016b): “it is almost impossible to determine the aristonectine affinities based only on the morphology of girdles and appendicular material". RNNGHP.04214-TA.2015.1 does not preserve enough diagnostic characters for an infrafamilial systematic determination if any, and its affinities thus remain unknown. For that reason, it is here referred as Elasmosauridae indet. Future discoveries are therefore required to determine whether the material reported in this study might be attributed to a new taxon.

\subsection{The Albian-Cenomanian fossil record of Ichthyosauria and Plesiosauria}

The exceptional richness in fossil vertebrates (Ichthyosauria, Plesiosauria and Chondrichthyes) of the documented site compared to other known Albian sites (Amédro, 2008; Bardet et al., 2014; Siversson and Machalski, 2017) could bring invaluable ecological constraints on the evolutionary history of two major groups of marine reptiles (Ichthyosauria and Plesiosauria). Marine strata of Albian age have yielded numerous marine reptile specimens worldwide. Ichthyosaurs have been reported in Europe (France, Poland, Italy, and UK), America (Canada, USA) and Russia and are referable to the family Ophthalmosaurinae and Platypterygiinae (e.g., Fischer et al., 2012; Bardet et al., 2014; Bardet et al., 2016). Plesiosaurians appear more diversified, belonging to Elasmosauridae, Pliosauridae, Leptocleididae and Polycotylidae and with a more widespread geographical distribution: Europe (France, Poland, and UK), America (Canada, USA, and Venezuela), Australia, Russia and Japan (Bardet et al., 2014; Bardet et al., 2016). However, for both groups, the identification at the infra-familial level proves to be difficult as many specimens correspond to isolated remains.

Concerning plesiosaurian material, the European Lower Cretaceous record is scarce, with only eight taxa recognized at the species level. Only one of them is referable to the elasmosaurid family and identifiable to genus and species levels (Lagenanectes richterae Sachs et al. 2017, from Germany), the systematic status of Gronausaurus being questionable (see Sachs et al. 2017). In the Albian strata, only six genera are recognized worldwide: 
Edgarosaurus (USA), Kronosaurus and Eromangasaurus carinognathus (Australia), Nichollssaura and Wapuskanectes (Canada), and the waste basket taxon Polyptychodon (Europe) whose material should be reconsidered separately (Bardet et al., 2014; 2018; Madzia, 2016). No sub-complete skeleton has been found in Europe and the material usually consists of isolated vertebrae, limb bones or teeth (see Persson, 1963), and cannot be identified to an infra-familial level except specimens belonging to Polyptychodon interruptus (Owen, 1841), which have been found in UK and France (Barrois, 1875; Persson, 1963; Buffetaut et al., 2005; Bardet et al., 2016). Isolated plesiosaurian teeth from the AlbianCenomanian strata of Annopol (Poland), have also been assigned to Polyptychodon interruptus (Bardet et al., 2016). However, Madzia (2016) considered P. interruptus as a nomen dubium. The reappraisal of Polyptychodon by Madzia (2016), led Madzia and Machalski (2017) to conclude that the Annopol material belongs to Pliosauridae and cannot be identified to an infra-familial level. The Albian strata in Europe have produced partial specimens of indeterminate Elasmosauridae from Poland and France. In France, isolated vertebrae and teeth from the Albian strata have been referred to Pliosauridae indet. and Polyptychodon, (see Buffetaut et al., 2005 for a review). Some other specimens have been referred to Cimoliasaurus (vertebral remains, Louppy, France, Albian), an assignation that needs a revision, Plesiosauria indet., and to Elasmosauridae indet. (vertebral or limb bone remains, Grandpré and Port-du-Rhône, France, Albian) see Persson (1963) for a review.

In Cenomanian strata, seven genera are recognized worldwide (Bardet et al., 2014; 2018) and come from USA (Thalassomedon, Plesiopleurodon, Eopolycotylus, Pahasapasaurus, Brachauchenius and Trinacromerum), and Europe (Polyptychodon; but see Madzia (2016) for discussion). The fossil record for the Cenomanian is thus more comprehensive than that of the Albian but the record in Europe, and especially France, remains poor.

Although the partial preservation of the specimen RNNGHP.04214-TA.2015.1 hampers taxonomic assessment further than the family level, it represents the most complete plesiosaurian specimen found in the Albian strata of France so far, the most complete elasmosaurid plesiosaur found in European Albian and Cenomanian strata, and also one of the most complete Elasmosauridea from the Albian worldwide.

\subsection{Taphonomical and paleoenvironemental implications}

The sediments of the Mortoniceras fallax ammonite zone were deposited during one of the largest marine transgression of the Cretaceous Period, during which the sea level may have risen by more than $75 \mathrm{~m}$ (Haq, 2014). Such a dramatic rise in sea level would have shifted detrital depositional systems landward, which would certainly account for the low deposition rate of the sediments seen at the study locality and the condensed nature of the deposits of adjacent areas. Alternatively, or perhaps additionally, higher sea level would have increased inter-basin connectivity and facilitated the development of stronger deep bottom currents (Delamette, 1988), which would also explain reduced sedimentation rates. Concomitantly, seawater temperatures increased markedly, as reflected by a shift toward lower $\delta^{18} \mathrm{O}$ values in bulk carbonate, benthic foraminiferal calcite and fish tooth apatite in Atlantic and Southern Ocean deep-sea sites immediately above the first occurrence of E. turriseiffelii (Bralower and Siesser, 1992; Clarke and Jenkyns, 1999; Pucéat et al., 2003; Friedrich et al., 2012). As suggested for many Cretaceous and Jurassic OAEs (Jenkyns, 2010), warming and rising sea level may have favoured a loop of biogeochemical feedbacks that promoted increased runoff, higher nutrient input and export productivity, eventually leading to basinal water stratification and lower oxygenation of bottom sea water masses. Such a scenario is supported by global phosphorus accumulation rates, which show a dramatic increase in the late Albian (Föllmi, 1995). Oxygen levels fluctuating between oxic and dysoxic near the sediment-water interface would have promoted the widespread formation of glauconite in the organic-rich portion of 
the sedimentary column (fossil remains and faecal pellets). Besides, dysoxic conditions favour, through the bacteria-mediated remineralisation of phosphorus, higher levels of phosphate saturation in sediment porewaters, therefore enhancing the preservation of vertebrate remains (Föllmi, 1996; Schenau et al., 2000; Suan et al., 2012). Accordingly, the fossiliferous glauconite-rich bed investigated herein would be the local signature of transient changes in sedimentation and oxygenation dynamics that may have affected much larger paleogeographic areas. The condensed phosphoritic horizon containing glauconite (Mortoniceras fallax ammonite Zone) documented in Poland (Annopol) may represent another record of this perturbation (Dubicka and Machalski, 2017).

If correct, these interpretations of the preservation and sedimentological framework of the specimen RNNGHP.04214-TA.2015.1 and associated vertebrates reported herein open an interesting avenue for future discoveries. A transient episode of lower sedimentation rates and oxygenation would have favored the widespread concentration of both invertebrates and vertebrate remains at a relatively large geographic scale. This reasoning is in accordance with the discovery of isolated bones associated with rounded chert and quartz pebbles (i.e., possible gastroliths) within fossiliferous glauconite-rich bed along the road, $400 \mathrm{~m}$ west from the plesiosaur excavation locality; the articulated series of ichthyosaur vertebrae (RNNGHP.04214-TA.061) findings confirm that the same bed preserves vertebrate remains at the kilometer-scale, and indicates that more ichthyosaur remains, despite their limited evidence in the present report, and plesiosaur remains should be expected with future investigations. Altogether, these petrographic, sedimentological and paleontological data indicate that the study bed very likely contains abundant, mostly articulated vertebrate remains and can be defined as a Konzentrat-Lagerstätte sensu Seilacher 1970. Future excavations within this bed in the area would certainly permit the discovery of new invaluable specimens of marine reptiles and hence fill the Albian gap in the fossil record.

\section{Conclusions}

The Tartonne area (Alpes de Haute-Provence, SE France) corresponds to the pelagic domain of the French Subalpine Basin. The studied section (Les Faïsses section), is characterized by the presence of a massive one meter-thick greenish-gray bed, in which the exceptional concentration of fossil remains was discovered. The very rich ammonite fauna, often with large sized specimens, indicates the Mortoniceras fallax ammonite Zone and the calcareous nannofossil date the level to the NC10a zone hence in the middle upper Albian. Vertebrate remains are represented by Chondrichthyans (five shark species belonging to Lamniformes and Hexanchiformes), Ichthyosauria (isolated tooth belonging to Ophtalmosauridae indet.) and Plesiosauria (partial post-cranial skeleton belonging to Elasmosauridae indet.). The plesiosaurian specimen represents the most complete plesiosaurian specimen found in the Albian strata of France so far, the most complete elasmosaurid plesiosaur found in European Albian and Cenomanian strata, and also one of the most complete Elasmosauridea from the Albian worldwide. Altogether, the petrographic, sedimentological and paleontological data indicate that the study bed very likely contains abundant, mostly articulated vertebrate remains and can be defined as a KonzentratLagerstätte. Future excavations within this bed in the area would certainly allow the discovery of new invaluable specimens of marine reptiles and hence fill the Albian gap in the fossil record.

\section{Acknowledgements}

Anne-Lise Charruault (ISE-M, University of Montpellier) helped with the restauration of some shark teeth. BSM thanks a financial support from the team Climat at CEREGE. Lionel Marié prepared the petrographic thin slides, Daniel Borschneck performed the XRD analyses, 
Corinne Sonzoni analyzed the C-O isotopes and Bertrand Devouard helped BSM with the SEM-EDS analyses. The G.P.A. (Groupe de recherche en Paléobiologie et biostratigraphie des Ammonites at La Mure-Argens, France) is acknowledged for having made its preparation and photography laboratories available (ammonites' preparation). We are also grateful to Francesco Barriani and Pierre-Jean Bernard (Guard-technicians of the Réserve Naturelle Nationale Géologique de Haute-Provence), Albin Maurel (communal employee of Tartonne) and all the volunteers that provided invaluable technical, logistical and physical help during the field campaigns. Many thanks to François Serra (Mayor of Tartonne) and Alain Castan (Departmental Director of the NFB) for their authorizations to dig and search on communal ground. Plesiosaur specimen preparation and cast were performed by Yvain Leclerc (palaeontologist and independent preparator). The manuscript benefited from review comments by David K. Watkins (University of Nebraska-Lincoln) and an anonymous reviewer, as well as from the editor (Eduardo Koutsoukos) and associate editor (Marcin Machalski).

\section{Funding}

This work was supported by the Departmental Council of the Alpes-de-Haute-Provence, which financed part of the excavations, the security on site, the extraction of the vertebrate remains and the realization of the casts.

\section{References}

Albright, L.B.I., Gillette, D.D, Titus, A.L., 2007. Plesiosaurs from the Upper Cretaceous (Cenomanian-Turonian) Tropic Shale of southern Utah, Part 2: Polycotylidae. Journal of Vertebrate Paleontology 27, 41-58.

Allemand, R., Bardet, N., Houssaye, A., Vincent P., 2017. Virtual reexamination of a plesiosaurian specimen (Reptilia, Plesiosauria) from the Late Cretaceous (Turonian) of Goulmima, Morocco, using computed tomography. Journal of Vertebrate Paleontology 37. Doi: $10.1080 / 02724634.2017 .1325894$.

Amédro, F., 1980. Ammonites. In: Robaszynski, F., Amédro, F (Coords.), Foucher, J.C., Gaspard, D., Magniez-Jannin, F., Manivit, H., Sornay, J., Synthèse biostratigraphique de l'Aptien au Santonien du Boulonnais à partir de sept groupes paléontologiques: foraminifères, nannoplancton, dinoflagellés et macrofaunes. Zonations Micropaléontologiques intégrées dans le cadre du Crétacé boréal nord-européen. Revue de Micropaléontologie 22, 195-321.

Amédro, F., 2008. Support for a Vraconnian Stage between the Albian sensu stricto and the Cenomanian (Cretaceous System). Carnets de Géologie, 2008/02.

Amédro, F., Matrion, B., 2014. L'étage Albien dans sa région-type, l'Aube (France) : une synthèse dans un contexte sédimentaire global. Carnets de Géologie 14, 69-128.

Amédro, F., Matrion, B., Tomasson, R., Magniez-Jannin, F., Colleté, C., 2004. L'Albien supérieur de Vallentigny dans la région stratotypique (Aube, F.): nouvelles données et révision de l'ammonite Mortoniceras (M.) inflatum (J. Sowerby, 1818). Bulletin de la Société Géologique de Normandie et des Amis du Muséum du Havre 90, 5-28.

Andrews, C.W., 1910. A descriptive catalogue of marine reptiles of the Oxford Clay - Part 1. British Museum (Natural History), London, 205 pp.

Araújo, R., Polcyn, M.J., Lindgren, J., Jacobs, L.L., Schulp, A.S., Mateus, O., Olimpio Gonçalves, A., Morais, M.-L., 2015. New aristonectine elasmosaurid plesiosaur specimens from the Early Maastrichtian of Angola and comments on paedomorphism in plesiosaurs. Netherlands Journal of Geosciences 94, 93-108.

Banerjee, S., Bansal, U., Vilas Thorat, A., 2016. A review on palaeogeographic implications and temporal variation in glaucony composition. Journal of Palaeogeography 5, 43-71. 
Barale, L., d'Atri, A., Piana, F., 2016. The Meso-Cenozoic stratigraphic succession of the Col de Braus area (Maritime Alps, SE France). Journal of Maps 12, 804-814.

Bardet, N., Falconnet, J., Fischer, V., Houssaye, A., Jouve, S., Pereda Suberbiola, X., PérezGarcía, A., Rage, J.C., Vincent, P., 2014. Mesozoic marine reptile palaeobiogeography in response to drifting plates. Gondwana Research 26, 869-887.

Bardet, N., Fischer, V., Machalski, M., 2016. Large predatory marine reptiles from the Albian-Cenomanian of Annopol, Poland. Geological Magazine 153, 1-16.

Bardet, N., Segura, M., Pérez-García, A., 2018. A plesiosaur (Reptilia, Sauropterygia) from the Cenomanian (Late Cretaceous) of Algora (Guadalajara Province, Central Spain). Cretaceous Research 91, 33-40.

Barnett, A., Braccini, J.M., Awruch, C.A., Ebert, D. A. 2012. An overview on the role of Hexanchiformes in marine ecosystems: biology, ecology and conservation status of a primitive order of modern sharks. Journal of Fish Biology 80, 966-90.

Barrois, C., 1875. Les reptiles du terrain crétacé du nord-est du Bassin de Paris. Bulletin Scientifique, Historique et Littéraire du Nord 6, 11.

Baur, G., 1887. On the morphology and origin of the Ichthyopterygia. American Naturalist 21, 837-840.

Benson, R.B.J., Druckenmiller, P.S., 2014. Faunal turnover of marine tetrapods during the Jurassic-Cretaceous transition. Biological Reviews 89, 1-23.

Benson, R.B.J., Butler, R.J., Lindgren, J., Smith, A.S., 2010. Mesozoic marine tetrapod diversity: mass extinctions and temporal heterogeneity in geological megabiases affecting vertebrates. Proceedings of the Royal Society B: Biological Sciences 277, 829-834.

Benson, R.B.J., Ketchum, H.F., Naish, D., Turner, L.E., 2013. A new leptocleidid (Sauropterygia, Plesiosauria) from the Vectis Formation (Early Barremian-early Aptian; Early Cretaceous) of the Isle of Wight and the evolution of Leptocleididae, a controversial clade. Journal of Systematic Palaeontology 11, 233-250.

Bert, D., 2013. Factors of intraspecific variability in ammonites, the example of Gassendiceras alpinum (d'Orbigny, 1850) (Hemihoplitidae, Upper Barremian). Annales de Paléontologie 100, 217-236.

Bert, D., 2014. L'influence de la variabilité intraspécifique sur la taxinomie, la biostratigraphie et l'évolution des ammonites : une approche paléobiologique. Exemples pris dans le Jurassique supérieur et le Crétacé inférieur. PhD Thesis, Université de Rennes 1, 739 pp.

Black, M., 1972. British Lower Cretaceous coccoliths. I. Gault Clay. Monograph of the Palaeontographical Society, 1-48.

Black, M., 1973. British Lower Cretaceous coccoliths. I. Gault Clay. Monograph of the Palaeontographical Society, 49-112.

Black, M., 1975. British Lower Cretaceous coccoliths. I. Gault Clay. Monograph of the Palaeontographical Society, 113-142.

Blainville, H.M.D. de., 1835. Système d'Herpétologie. Nouvelles Annales du Muséum (national) d'Histoire naturelle de Paris 4, 233-296.

Bodin, S., Meissner, P., Janssen, N.M.M., Steuber, T., Mutterlose, J., 2015. Large igneous provinces and organic carbon burial: Controls on global temperature and continental weathering during the Early Cretaceous. Global and Planetary Change 133, 238-253.

Bornemann, A., Mutterlose, J., 2006. Size analyses of the coccolith species Biscutum constans and Watznaueria barnesiae from the Late Albian "Niveau Breistroffer" (SE France): taxonomic and palaeoecological implications. Geobios 39, 599-615.

Bornemann, A., Pross, J., Reichelt, K., Herrle, J.O., Hemleben, C., Mutterlose, J., 2005. Reconstruction of short-term palaeoceanographic changes during the formation of the 
Late Albian 'Niveau Breistroffer' black shales (Oceanic Anoxic Event 1d, SE France). Journal of the Geological Society 162, 623-639.

Bown, P.R., 2001. Calcareous nannofossils of the Gault, Upper Greensand and Glauconitic Marl (Middle Albiane-Lower Cenomanian) from the BGS Selborne boreholes, Hampshire. Proceedings of the Geologists' Association 112, 223-236.

Bown, P.R., Young, J.R., 1998. Techniques. In: Bown, P.R. (Ed.), Calcareous nannofossil biostratigraphy. Kluwer Academic Publishers, Dortrecht, pp. 16-28.

Bralower, T., Siesser, W., 1992. Cretaceous calcareous nannofossil biostratigraphy of Sites 761, 762 and 763, Exmouth and Wombat Plateaus, northwest Australia. Proceedings of the Ocean Drilling Program, Scientific Results 122, 529-556.

Bralower, T.J., Sliter, W.V., Arthur, M.A., Leckie, R.M., Allard, D., Schlanger, S.O., 1993. Dysoxic/anoxic episodes in the Aptian-Albian (Early Cretaceous). Geophysical Monograph 77, 5-37.

Bréhéret, J.-G., 1991. Glauconitization episodes in marginal settings as echoes of midCretaceous anoxic events in the Vocontian basin (SE France), in: Tyson, R.V., Pearson, T.H. (Eds.), Modern and ancient continental shelf anoxia. Geological Society Special Publication 58, pp. 415-425.

Bréhéret, J.-G., 1997. L'Aptien et l'Albien de la Fosse vocontienne (des bordures au bassin). Evolution de la sédimentation et enseignements sur les événements anoxiques. Société Géologique du Nord 25, 614 pp..

Breistroffer, M., 1940. Révision des ammonites du Vraconien de Salazac (Gard), et considérations générales sur ce sous-étage albien. Travaux du Laboratoire de Géologie de Grenoble 22, $101 \mathrm{pp}$.

Brown, D.S., 1981. The English Upper Jurassic Plesiosauroidea (Reptilia) and a review of the phylogeny and classification of the Plesiosauria. Bulletin of the British Museum (Natural History), Geology Series 35, 253-344.

Brown, D.S., 1993. A taxonomic reappraisal of the families Elasmosauridae and Cryptoclididae (Reptilia: Plesiosauria). Revue de Paléobiologie, Special Volume 7, 9-16.

Buchy, M.C., 2005. An elasmosaur (Reptilia: Sauropterygia) from the Turonian (Upper Cretaceous) of Morocco. Carolinea 63, 5-28.

Buffetaut, E., Cappetta, H., Gayet, M., Martin, M., Moody, R.T.J., Rage, J.-C., Taquet, P., Wellnhofer, P., 1981. Les vertébrés de la partie moyenne du Crétacé en Europe. Cretaceous Research 2, 275-281.

Buffetaut, E., Colleté, C., Dubus, B., Petit, J.-L., 2005. The "sauropod" from the Albian of Mesnil-Saint-Père (Aube, France): a pliosaur, not a dinosaur. Carnet de géologie 26, 2005/01.

Cabrera, A., 1941. Un Plesiosaurio nuevo del Cretaceo del Chubut. Revista del Museo de La Plata 2, 113-130.

Carpenter, K., 1996. A review of short-necked plesiosaurs from the Cretaceous of the Western Interior, North America. Neues Jahrbuch für Geologie und Paläontologie, Abhandlungen 201, 259-287.

Clarke, L.J., Jenkyns, H.C., 1999. New oxygen isotope evidence for long-term Cretaceous climatic change in the Southern Hemisphere. Geology 27, 699-702.

Cope, E.D., 1869. Synopsis of the extinct Batrachia and Reptilia of North America. Transactions of the North American Philosophical Society 14, 1-252.

Cotillon, P., 1971. Le Crétacé inférieur de l'Arc subalpin de Castellane entre l'Asse et le Var. Mémoires du Bureau de Recherches Géologiques et Minières 68, 1-313.

Cruickshank, A.R.I., Fordyce, R.E., 2002. A new marine reptile (Sauropterygia) from New Zealand: further evidence for a Late Cretaceous austral radiation of cryptoclidid plesiosaurs. Palaeontology 45, 557-575. 
Crux, J.A., 1991. Albian calcareous nannofossils from the Gault Clay of Munday's Hill (Bedfordshire, England). Journal of Micropalaeontology 10, 203-221.

De Baets, K., Bert, D., Hoffmann, R., Monnet, C., Yacobucci, M.M., Klug, C., 2015. Ammonoid intraspecific variability. In: Klug, C., Korn, D., De Baets, K., Kruta, I., Mapes, R.H. (Eds.), Ammonoid Paleobiology: From Anatomy to Ecology. Topics in Geobiology 43. Springer, pp. 359-426.

De Blainville, H.D., 1835. Description de quelques espèces de reptiles de la Californie, précédée de l'analyse d'un système général d'Erpétologie et d'Amphibiologie. Nouvelles Annales Musée (national) d'Histoire Naturelle Paris 4, 233-296.

Delamette, M., 1988. Relation between the condensed Albian deposits of the Helvetic domain and the oceanic current-influenced continental margin of the northern Tethys. Bulletin de la Société Géologique de France 5, 739-745.

Druckenmiller, P.S., Russell, A.P., 2006. A new elasmosaurid plesiosaur (Reptilia: Sauropterygia) from the Lower Cretaceous Clearwater Formation, northeastern Alberta, Canada. Paludicola 5, 184-199.

Dubicka, Z., Machalski, M., 2017. Foraminiferal record in a condensed marine succession: a case study from the Albian and Cenomanian (mid-Cretaceous) of Annopol, Poland. Geological Magazine 154, 399-418.

Ebert, D.A., 1991. Observations on the predatory behaviour of the sevengill shark Notorynchus Cepedianus. South African Journal of Marine Science 11, 455-65.

Elloy, P., Faber, J., 1962. Stratigraphie, sédimentologie et paléontologie du Crétacé moyen et supérieur du bassin de Valréas et de son pourtour Gargasien à Coniacien. Société nationale des pétroles d'Aquitaine, Direction exploration et production, Centres de Recherches, Pau, 53 pp.

Evans, M., 2012. A new genus of plesiosaur (Reptilia: Sauropterygia) from the Pliensbachian (Early Jurassic) of England, and phylogeny of the Plesiosauria. PhD thesis, University of Leicester, $397 \mathrm{pp}$.

Fischer, V., 2012. New data on the ichthyosaur Platypterygius hercynicus and its implications for the validity of the genus. Acta Palaeontologica Polonica 57, 123-134.

Fischer, V., Clément, A., Guiomar, M., Godefroit, P., 2011. The first definite record of a Valanginian ichthyosaur and its implication for the evolution of post-Liassic Ichthyosauria. Cretaceous Research 32, 155-163.

Fischer V., Maisch, M.W., Naish, D., Kosma, R., Liston, J., Joger, U., Krüger, F.J., Pardo Pérez, J., Tainsh, J., Appleby, R.M., 2012. New ophthalmosaurid ichthyosaurs from the european lower Cretaceous demonstrate extensive ichthyosaur survival across the Jurassic-Cretaceous boundary. PLOS ONE 7, e29234.

Fischer, V., Arkhangelsky, M.S., Naish, D., Stenshin, I.M., Uspensky, G.N., Godefroit, P., 2014. Simbirskiasaurus and Pervushovisaurus reassessed: implications for the taxonomy and cranial osteology of Cretaceous platypterygiine ichthyosaurs. Zoological Journal of the Linnean Society 171, 822-841.

Fischer, V., Bardet, N., Benson, R.B.J., Arkhangelsky, M.S., Friedman, M., 2016. Extinction of fish-shaped marine reptiles associated with reduced evolutionary rates and global environmental volatility. Nature Communications 7, 10825.

Föllmi, K.B., 1996. The phosphorus cycle, phosphogenesis and marine phosphate-rich deposits. Earth-Science Reviews 40, 55-124.

Friedrich, O., Norris, R.D., Erbacher, J., 2012. Evolution of middle to Late Cretaceous oceans-A 55 m.y. record of Earth's temperature and carbon cycle. Geology 40, 107-110.

Friès, G., 1987. Dynamique du bassin subalpin méridional de l'Aptien au Cénomanien. École des mines de Paris, Université de Paris VI, Paris, 370 pp. 
Gale, A.S., Kennedy, W.J., Burnett, J.A., Caron, M., Kidd, B.E., 1996. The Late Albian to Early Cenomanian succession at Mont Risou near Rosans (Drôme, SE France): an integrated study (ammonites, inoceramids, planktonic foraminifera, nannofossils, oxygen and carbon isotopes). Cretaceous Research 17, 515-606.

Gale, A.S., Bown, P.R., Caron, M., Crampton, J., Crowhurst, S.J., Kennedy, W.J., Petrizzo, M. R., Wray, D.S., 2011. The uppermost Middle and Upper Albian succession at the Col de Palluel, Hautes-Alpes, France: An integrated study (ammonites, inoceramid bivalves, planktonic foraminifera, nannofossils, geochemistry, stable oxygen and carbon isotopes, cyclostratigraphy). Cretaceous Research 32, 59-130.

Gasparini, Z., Salgado, L., Casadio, S., 2003. Maastrichtian plesiosaurs from northern Patagonia. Cretaceous Research 24, 157-170.

Giraud, F., Olivero, D., Baudin, F., Reboulet, S., Pittet, B., Proux, O., 2003. Minor changes in surface-water fertility across the oceanic anoxic event 1d (latest Albian, SE France) evidenced by calcareous nannofossils. International Journal of Earth Sciences 92, 267284.

Gorski, C.A., Klüpfel, L.E., Voegelin, A., Sander, M., Hofstetter, T.B., 2013. Redox properties of structural Fe in clay minerals: 3. Relationships between smectite redox and structural properties. Environmental Science \& Technology 47, 13477-13485

Gyawali, B.R., Nishi, H., Takashima, R., Herrle, J.O., Takayanagi, H., Latil, J.-L., Iryu, Y., 2017. Upper Albian-upper Turonian calcareous nannofossil biostratigraphy and chemostratigraphy in the Vocontian Basin, southeastern France. Newsletters on Stratigraphy $50,111-139$.

Haq, B.U., Hardenbol, J., Vail, P.R., 1987. Chronology of fluctuating sea levels since the Triassic. Science 235, 1156-1167.

Haq, B.U., 2014. Cretaceous eustasy revisited. Global and Planetary Change 113, 44-58.

Hampe, O., 2013. The forgotten remains of a leptocleidid plesiosaur (Sauropterygia: Plesiosauroidea) from the Early Cretaceous of Gronau (Münsterland, Westphalia, Germany). Paläontologische Zeitschrift 87, 473-491.

Heithaus, M.R., 2001. Predator-prey and competitive interactions between sharks (Order Selachii) and dolphins (Suborder Odontoceti): a review. Journal of Zoology 253, 53-68.

Hennig, E., 1914. Die fischreste unter den funden der Tendaguru-Expedition. Archiv Für Biontologie 3, 293-312.

Hiller, N., Mannering, A.A., 2005. An unusual new elasmosaurid plesiosaur (Sauropterygia) from the Upper Haumurian (Maastrichtian) of the South Island, New Zealand. Memoirs of the Queensland Museum 51, 27-37.

Hiller, N., Mannering, A., Jones, C.M., Cruickshank, A.R.I., 2005. The nature of Mauisaurus haasti Hector, 1874 (Reptilia: Plesiosauria). Journal of Vertebrate Paleontology 25, 588601.

Janiszewska, K., Mazur, M., Machalski, M., Stolarski, J., 2018. From pristine aragonite to blocky calcite: Exceptional preservation and diagenesis of cephalopod nacre in porous Cretaceous limestones. PLOS ONE 13, e0208598.

Jenkyns, H.C., 2010. Geochemistry of oceanic anoxic events. Geochemistry, Geophysics, Geosystems 11, Q03004.

Kaim, A., Kobayashi, Y., Echizenya, H., Jenkins, R.G., Tanabe, K., 2008. Chemosynthesisbased associations on Cretaceous plesiosaurid carcasses. Acta Palaeontologica Polonica 53, 97-104.

Kear, B.P., 2005. A new elamosaurid plesiosaur from the Lower Cretaceous of Queensland, Australia. Journal of Vertebrate Paleontology 25, 792-805.

Kear, B.P., 2006. Marine reptiles from the Lower Cretaceous of South Australia: elements of a high-latitude cold-water assemblage. Palaeontology 49, 837-856. 
Kennedy, W.J., Latil, J.-L., 2007. The Upper Albian ammonite succession in the Montlaux section, Hautes-Alpes, France. Acta Geologica Polonica 57, 453-478.

Kerckhove, C., Roux, M., 1976. Notice explicative de la feuille de Castellane à 1/50000, $\mathrm{n}^{\circ}$ 971. Bureau de Recherches Géologique et Minières.

Ketchum, H.F., Benson, R.B.J., 2010. Global interrelationships of Plesiosauria (Reptilia, Sauropterygia) and the pivotal role of taxon sampling in determining the outcome of phylogenetic analyses. Biological Reviews 85, 361-392.

Knutsen, E.M., Druckenmiller, P.S., Hurum, J.H., 2012. Two new species of long-necked plesiosaurians (Reptilia: Sauropterygia) from the Upper Jurassic (Middle Volgian) Agardhfjellet Formation of central Spitsbergen. Norwegian Journal of Geology 92, 187212.

Kubo, T., Mitchell, M.T., Henderson, D.M., 2012. Albertonectes vanderveldei, a new elasmosaur (Reptilia, Sauropterygia) from the Upper Cretaceous of Alberta. Journal of Vertebrate Paleontology 32, 557-572.

Kulicki, C., Tanabe, K., Landman, N.H., Kaim, A., 2015. Ammonoid shell microstructure. In Klug, C., Korn, D., De Baets, K., Kruta, I., Mapes, R.H. (Eds.), Ammonoid paleobiology: From anatomy to ecology. Topics in Geobiology. Springer, Dordrecht, 321-357.

Latil, J.-L., 1995. The Dispar Zone in South-East France and comments about the biozonation of Albian in the tethyan realm: biostratigraphy and paleontology (Ammonites). In: Bulot, L., Argot, M., Arnaud, H. (Eds.), Lower Cretaceous cephalopod of the Western Tethys: recent developments, regional synthesis and outstanding problems. Laboratoire de Géologie de l'Université Joseph Fournier de Grenoble, 67-111.

Lowenstam, H.A., Weiner, S., 1989. On biomineralization. Oxford University Press, New York, $324 \mathrm{pp}$.

Madzia, D., 2016. A reappraisal of Polyptychodon (Plesiosauria) from the Cretaceous of England. PeerJ 4, e1998.

Madzia, D., Machalski, M., 2017. Isolated pliosaurid teeth from the Albian-Cenomanian (Cretaceous) of Annopol, Poland. Acta Geologica Polonica 67, 393-403.

Martin, J.E., Amiot, R., Lécuyer, C., Benton, M.J., 2014. Sea-surface temperature contributes to marine crocodylomorph evolution. Nature Communications 5, 4658.

Masse, J.-P., Philip, J., 1976. Paléogéographie et tectonique du Crétacé moyen de Provence : révision du concept d'isthme durancien. Revue de Géographie Physique et de Géologie Dynamique 18, 49-66.

Masse, J.-P., Masse, P.-J.-L., Tronchetti, G., 1990. Variations sédimentaires sous contrôle tectonique durant l'Aptien supérieur - Cénomanien moyen à l'articulation des blocs provencal et languedocien (SE de la France); cadre paléocéanographique et implications paléogéographiques. Bulletin de la Société Géologique de France VI, 963-971.

McGowan, C., Motani, R., 2003. Ichthyopterygia. Handbuch der Paläoherpetologie, 8, 1-173.

Mutterlose, J., Bornemann, A., Herrle, J.O., 2009. The Aptian-Albian cold snap: Evidence for "mid" Cretaceous icehouse interludes. Neues Jahrbuch für Geologie und Paläontologie, Abhandlungen 252, 217-225.

Nagesan, R., 2017. Neck mobility of the Plesiosaur Nichollssaura borealis. PhD Thesis, University Calgary, $149 \mathrm{pp}$.

Neumann, A., Sander, M., Hofstetter, T.B., 2011. Redox properties of structural Fe in smectite clay minerals. In: Tratnyek, P.G., Grundl, T.J., Haderlein, S.B. (Eds.), Aquatic redox chemistry. American Chemical Society, pp. 361-379

Nicholson, D.B., Holroyd, P.A., Benson, R.B.J., Barrett, P.M., 2015. Climate-mediated diversification of turtles in the Cretaceous. Nature Communications 6, 7848.

O’Brien, C.L., Robinson, S.A., Pancost, R.D., Sinninghe Damsté, J.S., Schouten, S., Lunt, D.J., Alsenz, H., Bornemann, A., Bottini, C., Brassell, S.C., Farnsworth, A., Forster, A., 
Huber, B.T., Inglis, G.N., Jenkyns, H.C., Linnert, C., Litther, K., Markwick, P., McAnena, A., Mutterlose, J., Naafs, B.D.A., Püttmann, W, Sluijs, A., van Helmond, N.A.G.M., Vellekoop, J., Wagner, T., Wrobel, N.E., 2017. Cretaceous sea-surface temperature evolution: Constraints from $\mathrm{TEX}_{86}$ and planktonic foraminiferal oxygen isotopes. Earth-Science Reviews 172, 224-247.

Odin, G.S., Matter, A., 1981. De glauconiarum origine. Sedimentology 28, 611-641.

O'Keefe, F.R., Street, H.P., 2009. Osteology of the cryptocleidoid plesiosaur Tatenectes laramiensis, with comments on the taxonomic status of the Cimoliasauridae. Journal of Vertebrate Paleontology 29, 48-57.

Ogg, J.G., Ogg, G.M., Gradstein, F.M., 2016. A concise geologic time scale 2016. Elsevier, Amsterdam, $234 \mathrm{pp}$.

O'Gorman, J.P., 2016a. A small body sized non-aristonectine elasmosaurid (Sauropterygia, Plesiosauria) from the Late Cretaceous of Patagonia with comments on the relationships of the Patagonian and antarctic elasmosaurids. Ameghiniana 53, 245-268.

O'Gorman, J.P., 2016b. Reappraisal of Fresnosaurus drescheri (Plesiosauria; Elasmosauridae) from the Maastrichtian Moreno Formation, California, U.S.A. Cretaceous Research 68, 9-20.

O’Gorman, J.J.P., Gasparini, Z., Salgado, L., 2014. Reappraisal of Tuarangisaurus? cabazai (Elasmosauridae, Plesiosauria) from the Upper Maastrichtian of northern Patagonia, Argentina. Cretaceous Research 47, 39-47.

O’Gorman, J.P., Salgado, L., Olivero, E.B., Marenssi, S.A., 2015. Vegasaurus molyi, gen. et sp. nov. (Plesiosauria, Elasmosauridae), from the Cape Lamb Member (lower Maastrichtian) of the Snow Hill Island Formation, Vega Island, Antarctica, and remarks on Wedellian Elasmosauridae. Journal of Vertebrate Paleontology 35. Doi: $10.1080 / 02724634.2014 .931285$.

Otero, R.A., 2016. Taxonomic reassessment of Hydralmosaurus as Styxosaurus: new insights on the elasmosaurid neck evolution throughout the Cretaceous. PeerJ 4, e1777.

Otero, R.A., O'Gorman, J.P., 2013. Identification of the first postcranial skeleton of Aristonectes Cabrera (Plesiosauroidea, Elasmosauridae) from the upper Maastrichtian of the south-eastern Pacific, based on a bivariate graphic analysis. Cretaceous Research 41, $86-89$.

Otero, R.A., Soto-Acuña, S., Rubilar-Rogers, D. 2012. A postcranial skeleton of an elasmsaurid plesiosaur from the Maastrichtian of central Chile, with comments on the affinities of Late Cretaceous plesiosauroids from the Weddellian Biogeographic Province. Cretaceous Research 37, 89-99.

Otero, R.A., Soto-Acuña, S., Vargas, A.O., Rubilar-Rogers, D., 2014a. A new postcranial skeleton of an elasmosaurid plesiosaur from the Upper Cretaceous of central Chile and reassessment of the historic species Cimoliasaurus andium Deecke. Cretaceous Research 50, 31-331.

Otero, R.A., Soto-Acuña, S., O'Keefe, F.R., O'Gorman, J.P., Stinnesbeck, W., Suárez, M.E., Rubilar-Rogers, D., Salazar, S., Quinzio, L.A., 2014b. Aristonectes quiriquinensis sp. nov., a new highly derived elasmosaurid from the upper Maastrichtian of central Chile. Journal of Vertebrate Paleontology 34, 100-125.

Otero, R.A., O'Gorman, J.P., Hiller, N., O'Keefe, F.R., Fordyce. R.E., 2016. Alexandronectes zealandiensis gen. et sp. nov., a new aristonectine plesiosaur from the lower Maastrichtian of New Zealand. Journal of Vertebrate Paleontology 36. Doi: 10.1080/02724634.2015.1054494.

Owen, H.G., 2012. The Gault Group (Early Cretaceous, Albian) in East Kent, S.E. England; its lithology and ammonite biozonation. Proceedings of the Geologists' Association 123, $742-765$. 
Owen, R., 1841. Odontography; or, a Treatise on the Comparative Anatomy of the Teeth; their Physiological Relations, Mode of Development, and Microscopic Structure, in the Vertebrate Animals. Hippolyte Baillière, London.

Páramo Fonseca, M.E, O'Gorman, J.P. Gasparini, Z., Padilla, S., Parra Ruge, M.L., 2019. A new late Aptian elasmosaurid from the Paja Formation, Villa de Leiva, Colombia. Cretaceous Research 99, 30-40.

Persson, P.O., 1963. A revision of the classification of the Plesiosauria with a synopsis of the stratigraphical and geographical distribution of the group. Lunds Universitets Årsskrift, N.F. Avdelningen 2, 1-59.

Pucéat, E., Lécuyer, C., Sheppard, S.M., Dromart, G., Reboulet, S., Grandjean, P., 2003. Thermal evolution of Cretaceous Tethyan marine waters inferred from oxygen isotope composition of fish tooth enamels. Paleoceanography 18, 1029.

Reboulet, S., Giraud, F., Proux, O., 2005. Ammonoid Abundance Variations Related to Changes in Trophic Conditions Across the Oceanic Anoxic Event 1d (Latest Albian, SE France). Palaios 20, 121-141.

Reboulet, S., Rawson, P.F., Moreno-Bedmar, J.A., Aguirre-Urreta, M.B., Barragan, R., Bogomolov, Y., Company, M., Gonzalez-Arreola, C., Stoyanova, V.I., Lukeneder, A., Matrion, B., Mitta, V., Randrianaly, H., Vašíček, Z., Baraboshkin, E.J., Bert, D., Bersac, S., Bogdanova, T.N., Bulot, L.G., Latil, J.-L., Mikhailova, I.A., Ropolo, P., Szives, O., 2011. Report on the 4th International Meeting of the IUGS Lower Cretaceous Ammonite Working Group, the "Kilian Group" (Dijon, France, 30th August 2010). Cretaceous Research 32, 786-793.

Reboulet, S., Szives, O., Aguirre-Urreta, B., Barragan, R., Company, M., Idakieva, V., Ivanov, M., Kakabadze, M.V., Moreno-Bedmar, J.A., Sandoval, J., Baraboshkin, E.J., Çaglar, M.K., Főzy, I., Gonzalez-Arreola, C., Kenjo, S., Lukeneder, A., Raisossadat, S.N., Rawson, P.F., Tavera, J.M., 2014. Report on the 5th International Meeting of the IUGS Lower Cretaceous Ammonite Working Group, the Kilian Group (Ankara, Turkey, $31^{\text {st }}$ August 2013). Cretaceous Research 50, 126-137.

Reboulet, S., Szives, O., Aguirre-Urreta, B., Barragán, R., Company, M., Frau, C., Kakabadze, M.V., Klein, J. Moreno-Bedmar, J.A., Lukeneder, A., Pictet, A., Ploch, I., Raisossadat, S.N., Vašíček, Z., Baraboshkin, E.J., Mitta, V.V., 2018. Report on the 6th International Meeting of the IUGS Lower Cretaceous Ammonite Working Group, the Kilian Group (Vienna, Austria, 20th August 2017). Cretaceous Research 91, 100-110.

Roth, P.H., 1978. Cretaceous nannoplankton biostratigraphy and oceanography of the northwestern Atlantic Ocean. Initial Reports of the Deep Sea Drilling Project 44, 731760.

Roth, P.H., 1983. Jurassic and Lower Cretaceous calcareous nannofossils in the western North Atlantic (Site 534): biostratigraphy, preservation, and some observations on biogeography and palaeoceanography. Initial Reports of the Deep Sea Drilling Project 76, $587-621$.

Rubino, J.-L., Delamette, M., 1985. The Albian shelf of South East of France: an example of clastic sand distribution dominated by oceanic currents. 6th European Regional Meeting of Sedimentology, Lleida, 399-402.

Sachs, S., Kear, B.P., 2015. Postcranium of the paradigm elasmosaurid plesiosaurian Libonectes morgani (Welles, 1949). Geological Magazine 152, 694-710.

Sachs, S., Kear, B.P., 2017. Redescription of the elasmosaurid plesiosaurian Libonectes atlasense from the Upper Cretaceous of Morocco. Cretaceous Research 74, 205-222

Sachs, S., Hornung, J.J., Kear. B.P., 2017. A new basal elasmosaurid (Sauropterygia: Plesiosauria) from the Lower Cretaceous of Germany. Journal of Vertebrate Paleontology 37. Doi: 10.1080/02724634.2017.1301945. 
Saltzman, M.R., Thomas, E., 2012. Carbon isotope stratigraphy, In: Gradstein, F.M., Ogg, J.G., Schmitz, M.D., and Ogg, G. (Eds.), The Geologic Time Scale 2012. Elsevier, pp. 207-232.

Salvador, A., 1994. International stratigraphic guide: a guide to stratigraphic classification, terminology, and procedure, second edition. The Geological Society of America, Boulder, Colorado, $214 \mathrm{pp}$.

Sato, T., 2003. Terminonatator ponteixensis, a new elasmosaur (Reptilia: Sauropterygia) from the Upper Cretaceous of Saskatchewan. Journal of Vertebrate Paleontology 23, 89-103.

Sato, T., Hasegawa, Y., Manabe, M., 2006. A new elasmosaurid plesiosaur from the Upper Cretaceous of Fukushima, Japan. Palaeontology 49, 467-484.

Schenau, S.J., Slomp, C.P., De Lange, G.J., 2000. Phosphogenesis and active phosphorite formation in sediments from the Arabian Sea oxygen minimum zone. Marine Geology $169,1-20$.

Schlanger, S.O., Jenkyns, H.C., 1976. Cretaceous oceanic anoxic events: causes and consequences. Geologie en Mijnbouw 55, 179-184.

Scott, R.W., Formolo, M., Rush, N., Owens, J.D., Oboh-Ikuenobe, F., 2013. Upper Albian OAE 1d event in the Chihuahua Trough, New Mexico, USA. Cretaceous Research 46, $136-150$.

Seilacher, A., 1970. Begriff und Bedeutung der Fossil-Lagerstätten (Concept and meaning of fossil lagerstätten): Neues Jahrbuch für Geologie und Paläontologie, Abhandlungen 1970, 34-39.

Serratos, D.J., Druckenmiller, P., Benson. R.B.J., 2017. A new elasmosaurid (Sauropterygia, Plesiosauria) from the Bearpaw Shale (Late Cretaceous, Maastrichtian) of Montana demonstrates multiple evolutionary reductions of neck length within Elasmosauridae. Journal of Vertebrate Paleontology 37. Doi: 10.1080/02724634.2017.1278608.

Shamrock, J.L., Watkins, D.K., 2009. Evolution of the Cretaceous calcareous nannofossil genus Eiffellithus and its biostratigraphic significance. Cretaceous Research 30, 10831102.

Siversson, M., Machalski, M., 2017. Late late Albian (Early Cretaceous) shark teeth from Annopol, Poland. Alcheringa 41, 433-463.

Stevens, K.A., Parrish, M.J., 1999. Neck Posture and Feeding Habits of Two Jurassic Sauropod Dinosaurs. Science 284, 798-800.

Suan, G., Föllmi, K.B., Adatte, T., Bomou, B., Spangenberg, J.E., van de Schootbrugge, B., 2012. Major environmental change and bonebed genesis prior to the Triassic-Jurassic mass extinction. Journal of the Geological Society 169, 191-200.

Tallobre, C., Giresse, P., Bassetti, M.-A., Loncke, L., Bayon, G., Buscail, R., Tudryn, A., Zaragosi, S., 2019. Formation and evolution of glauconite in the Demerara Contourite depositional system related to NADW circulation changes during late Quaternary (French Guiana). Journal of South American Earth Sciences 92, 167-183.

Tronchetti, G., 1981. Les foraminifères crétacés de Provence (Aptien-Santonien). PhD Thesis, Université de Provence, Marseille, 559 pp.

Vincent, P., Bardet, N., Suberbiola, X.P., Bouya, B., Amaghzaz, M., Meslouh, S., 2011. Zarafasaura oceanis, a new elasmosaurid (Reptilia: Sauropterygia) from the Maastrichtian Phosphates of Morocco and the palaeobiogeography of latest Cretaceous plesiosaurs. Gondwana Research 19, 1062-1073.

Vincent, P., Bardet, N., Houssaye, A., Amaghzaz, M., Meslouh. S., 2013. New plesiosaur specimens from the Maastrichtian Phosphates of Morocco and their implications for the ecology of the latest Cretaceous marine apex predators. Gondwana Research 24, 796805 . 
Watkins, D.K., Bergen, J., 2003. Late Albian adaptive radiation in the calcareous nannofossil genus Eiffellithus. Micropaleontology 49, 231-252.

Welles, S.P., 1943. Elasmosaurid plesiosaurs, with description of new material from California and Colorado. University of California, Memoirs 13, 125-254.

Welles, S.P., 1952. A review of the North American Cretaceous elasmosaurs. University of California Publications in Geological Sciences 29, 47-143.

Welles, S.P., 1962. A new species of elasmosaur from the Aptian of Colombia and a review of Cretaceous plesiosaurs. University of California Publications in Geological Sciences 44, 1-96.

Wiffen, J., Moisley W.L., 1986. Late Cretaceous reptiles (Families Elasmosauridae and Pliosauridae) from the Mangahouanga Stream, North Island, New Zealand. New Zealand Journal of Geology and Geophysics 29:205-252. 


\section{Supplementary Data}

\begin{tabular}{|c|c|c|c|}
\hline \multicolumn{2}{|c|}{ STAGES } & ZONES & SUBZONES \\
\hline \multirow{13}{*}{$\begin{array}{l}Z \\
\text { Z } \\
\text { Z }\end{array}$} & \multirow{7}{*}{ upper } & Arrhaphoceras briacensis & \\
\hline & & Mortoniceras perinflatum & \\
\hline & & Mortoniceras rostratum & \\
\hline & & Mortoniceras fallax & \\
\hline & & Mortoniceras inflatum & \\
\hline & & Mortoniceras pricei & \\
\hline & & Dipoloceras cristatum & \\
\hline & \multirow{4}{*}{ middle } & Euhoplites lautus & \\
\hline & & Euhoplites loricatus & \\
\hline & & Honlites dentatus & Hoplites spathi \\
\hline & & Hoplites dentatus & Lyelliceras lyelli \\
\hline & \multirow{2}{*}{ lower } & Douvilleiceras mammillatum & Lyelliceras pseudolyelli \\
\hline & & Leymeriella tardefurcata & \\
\hline
\end{tabular}

Supplementary Data 1. Albian biostratigraphic zonal chart based on ammonites (from Reboulet et al., 2011, 2014).

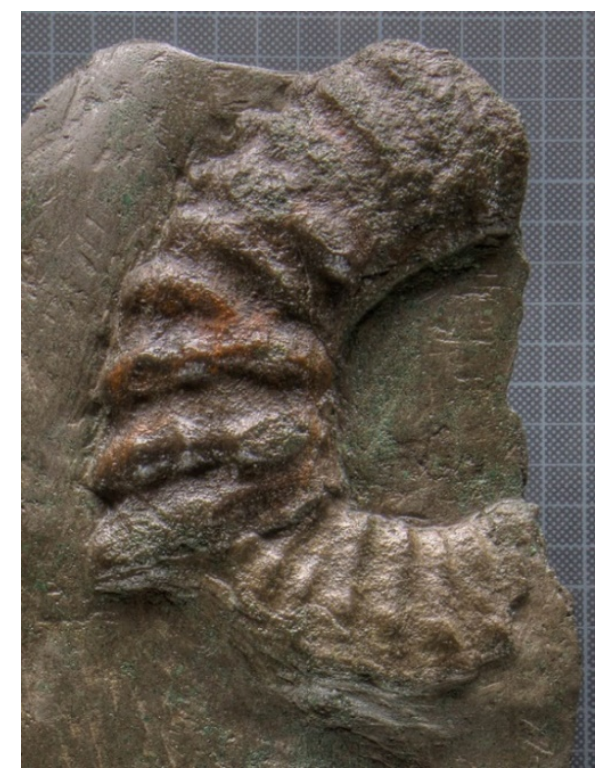

Supplementary Data 2. Mortoniceras rostratum (Sowerby, 1817), reposited in the RNNGHP (RNNGHP.04214-TA.130); Les Faïsses section, marlstone bed 99; D=140 mm. 


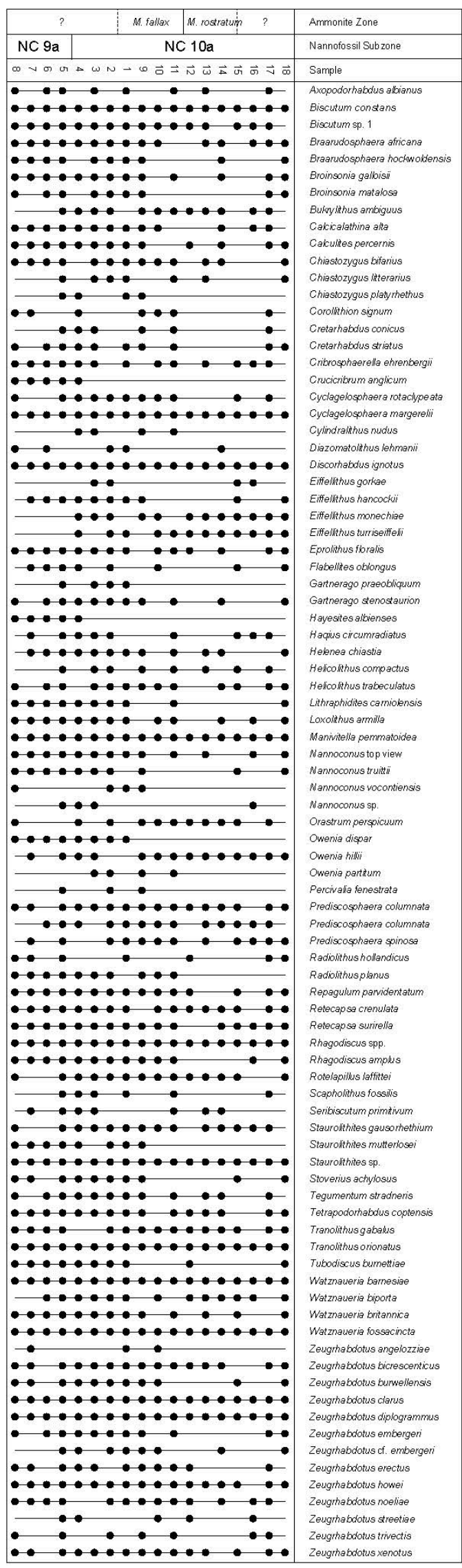

Supplementary Data 3. Presence/absence table of nannofossils sampled along the Les Faïsses section. 


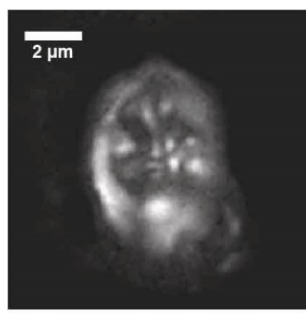

Axopodorhabdus albianus [1]

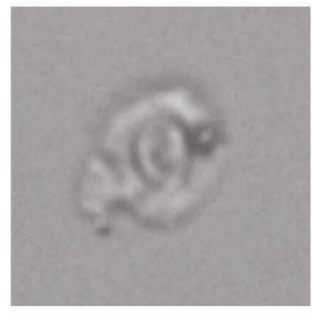

Biscutum sp. 1 [13]

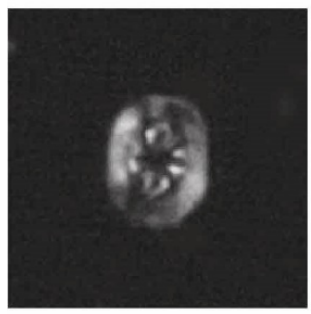

Bukrylithus ambiguus [11]

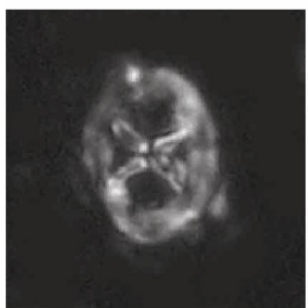

Chiastozygus litterarius [5]

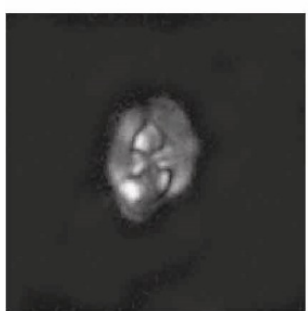

Crucicribrum anglicum [7]

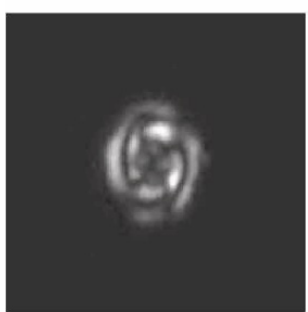

Eiffellithus hancockii [3] Eiffellithus monechiae [3]

Biscutum sp. 1 [13]

Calcicalathina alta [3]

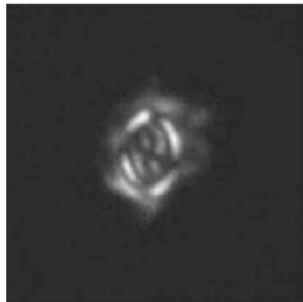

Biscutum sp. 1 [9]
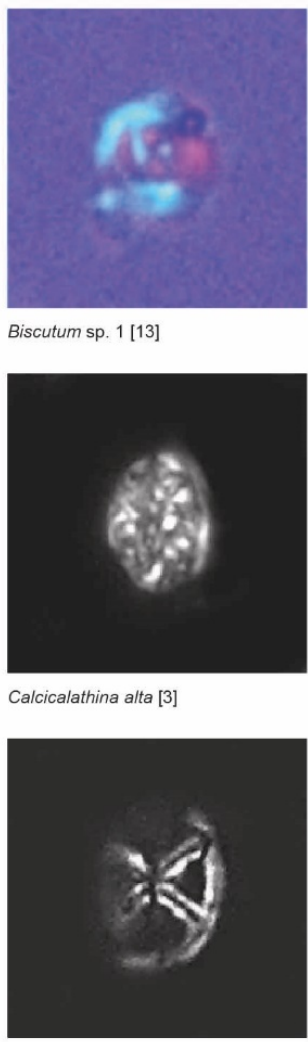

Chiastozygus platyrhethus [1]

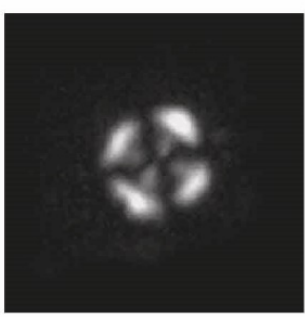

Cyclagelosphaera rotaclypeata [5]

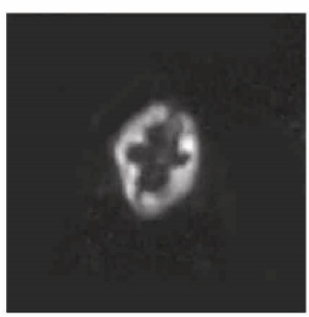

Eiffellithus monechiae [3]

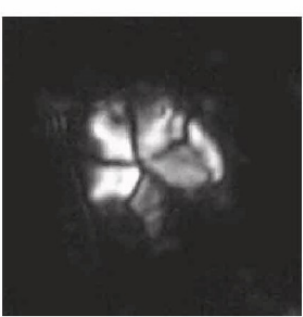

Braarudosphaera africana [1]

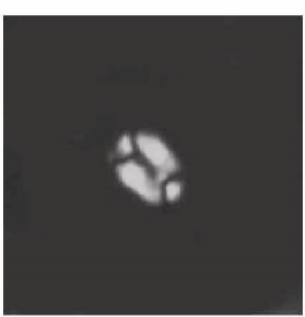

Calculites percernis [2]

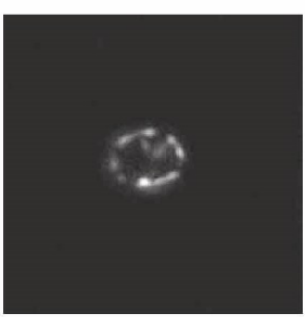

Corollithion signum [9]

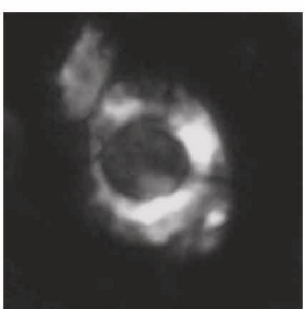

Cylindralithus nudus [4]

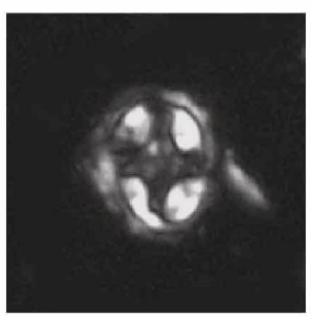

Eiffellithus monechiae [18]



Biscutum sp. 1 [9]

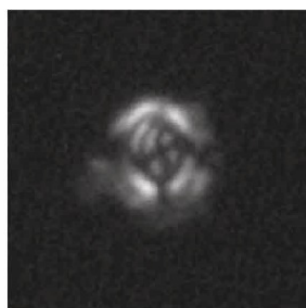

Biscutum sp. 1 [13]

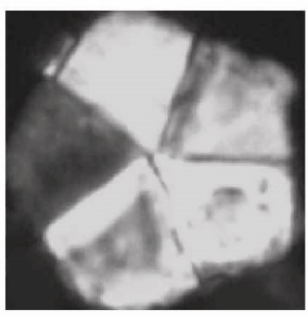

Braarudosphaera hockwoldensis [8]

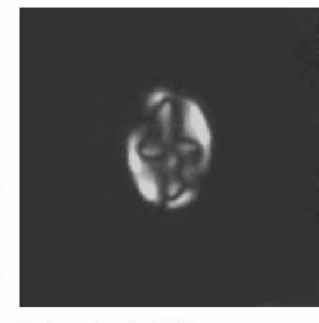

Broinsonia galloisii [3]

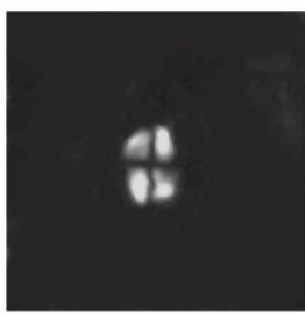

Calculites percernis [2]

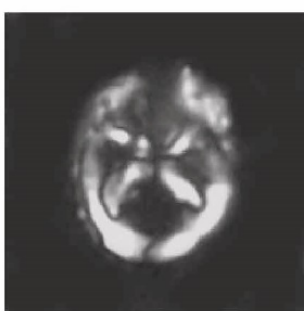

Chiastozygus bifarius [2]

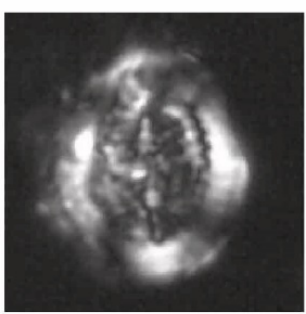

Cretarhabdus conicus [4]

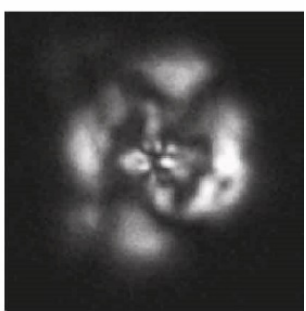

Cretarhabdus conicus [11]

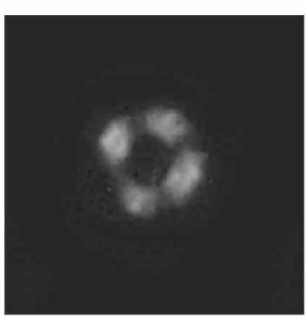

Diazomatolithus lehmanii [1]

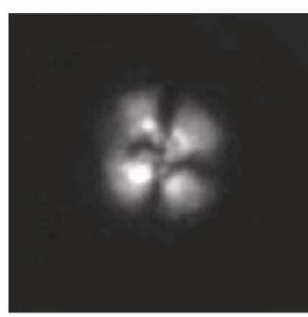

Discorhabdus ignotus [8]

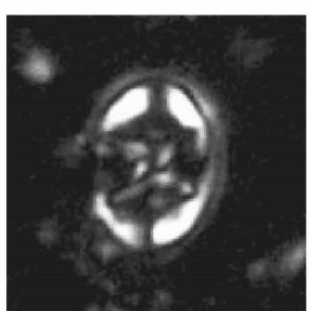

Eiffellithus turriseiffelii [4]

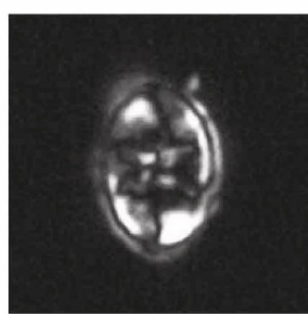

Eiffellithus turriseiffelii [11]

Supplementary Data 4A. Calcareous nannofossils observed in the Les Faïsses section. The species names and the sample number (in brackets) from which the calcareous nannofossil was photographed are given under each picture. 

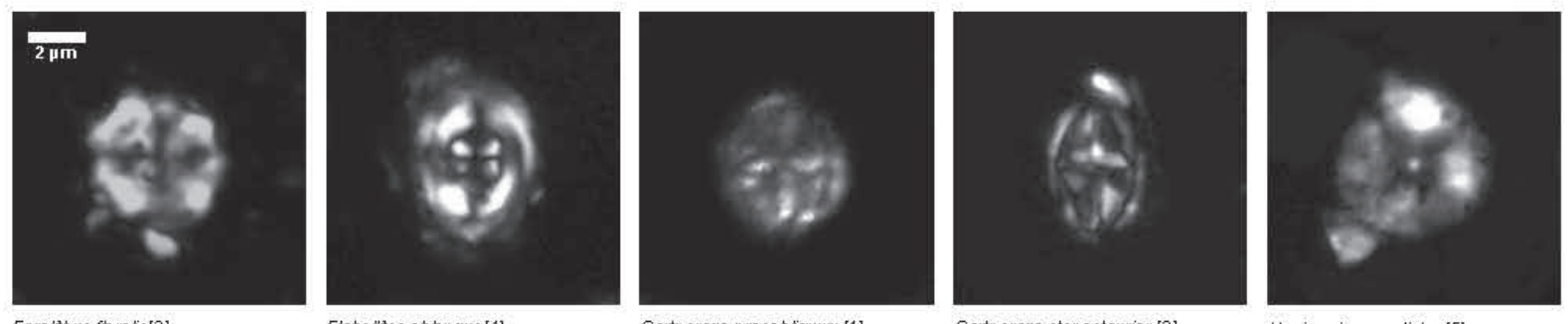

Eproikhus fioralis [2]

Flabellies obbongus [4]

Gartnerago pracobliquum [1]

Gartnerago stenostaurion [3]

Haquis circumradiatus [5]
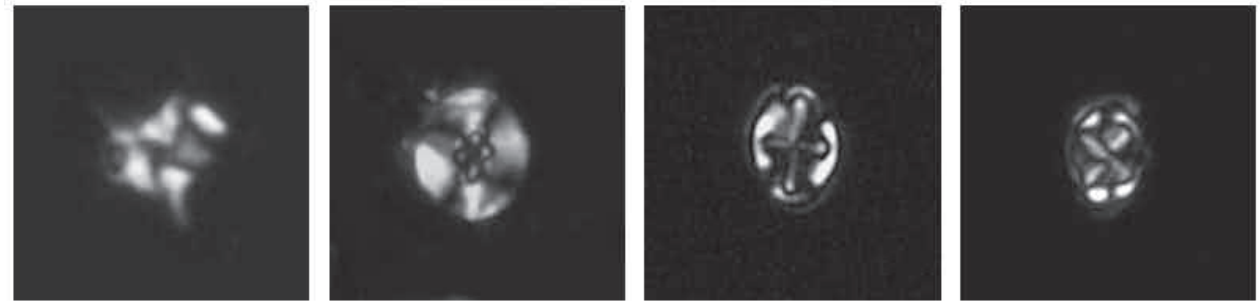

Heienea chiastia [2]

Heliconithus compactus [11]

Hellco Nithus trabe culatus [9]
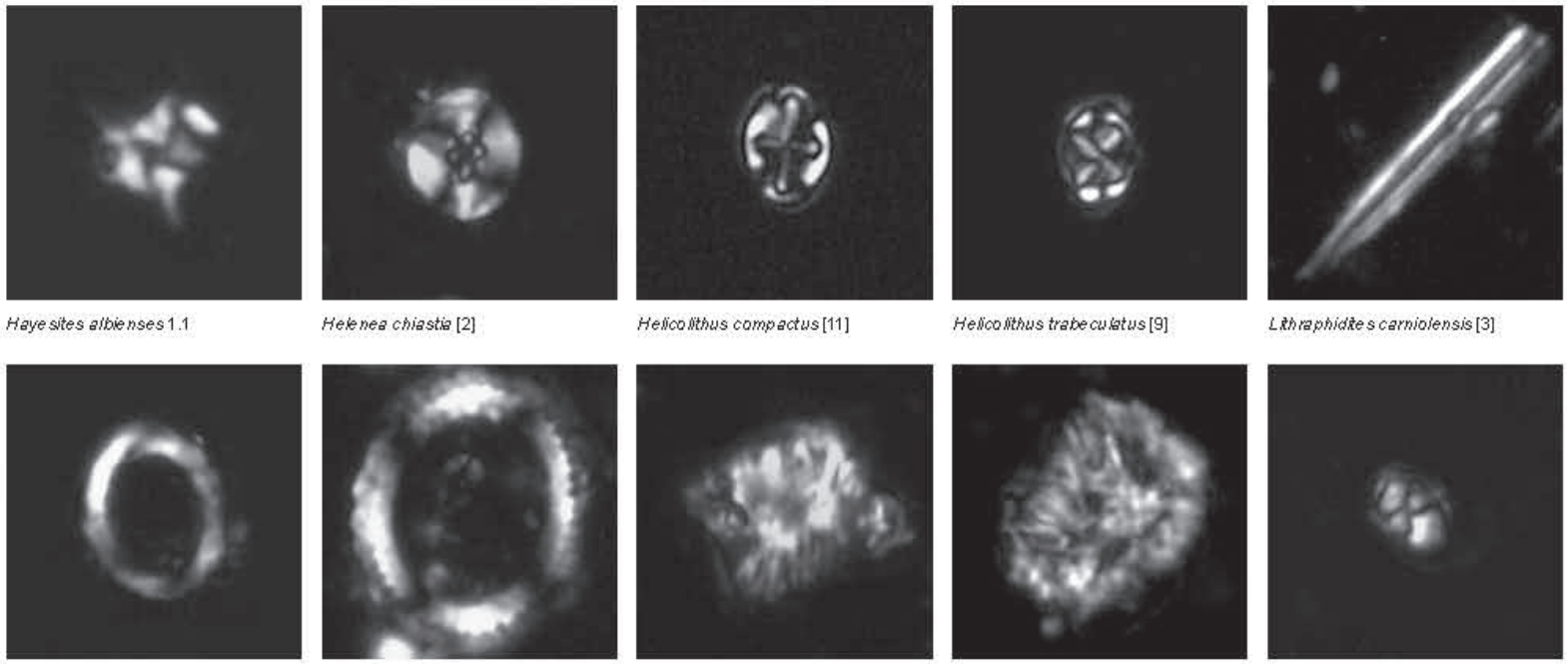

Lkhraphidte scarniolensis [3]

Loxoulthus armilla [1]

Manivitelis pemmatoisea [4]

Nannoconus trukt.i. [2]

Namnoconus vocontie nsis [8]

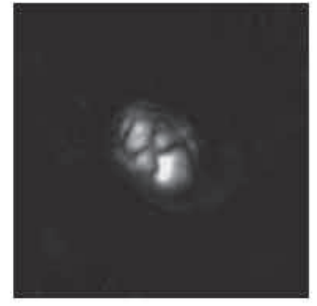

Owenia dispar[5]

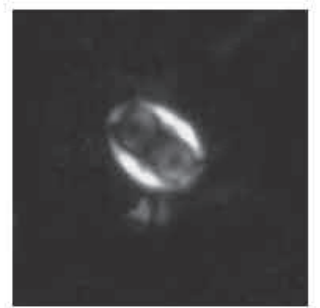

Owenia hivij[5]

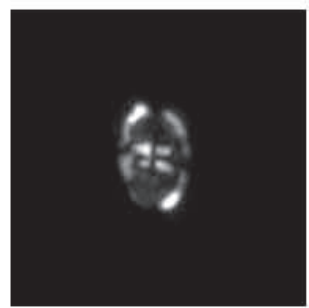

Owenis partitum [3]

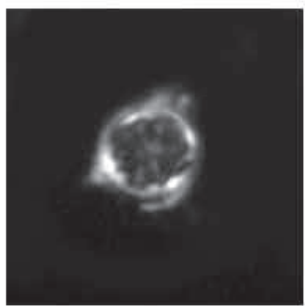

Rotelapilus isfote [ [9]

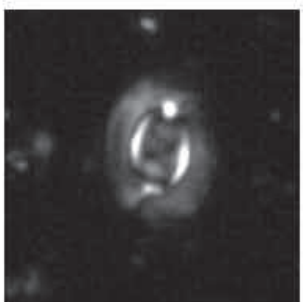

Seribiscutum primitivum [3]
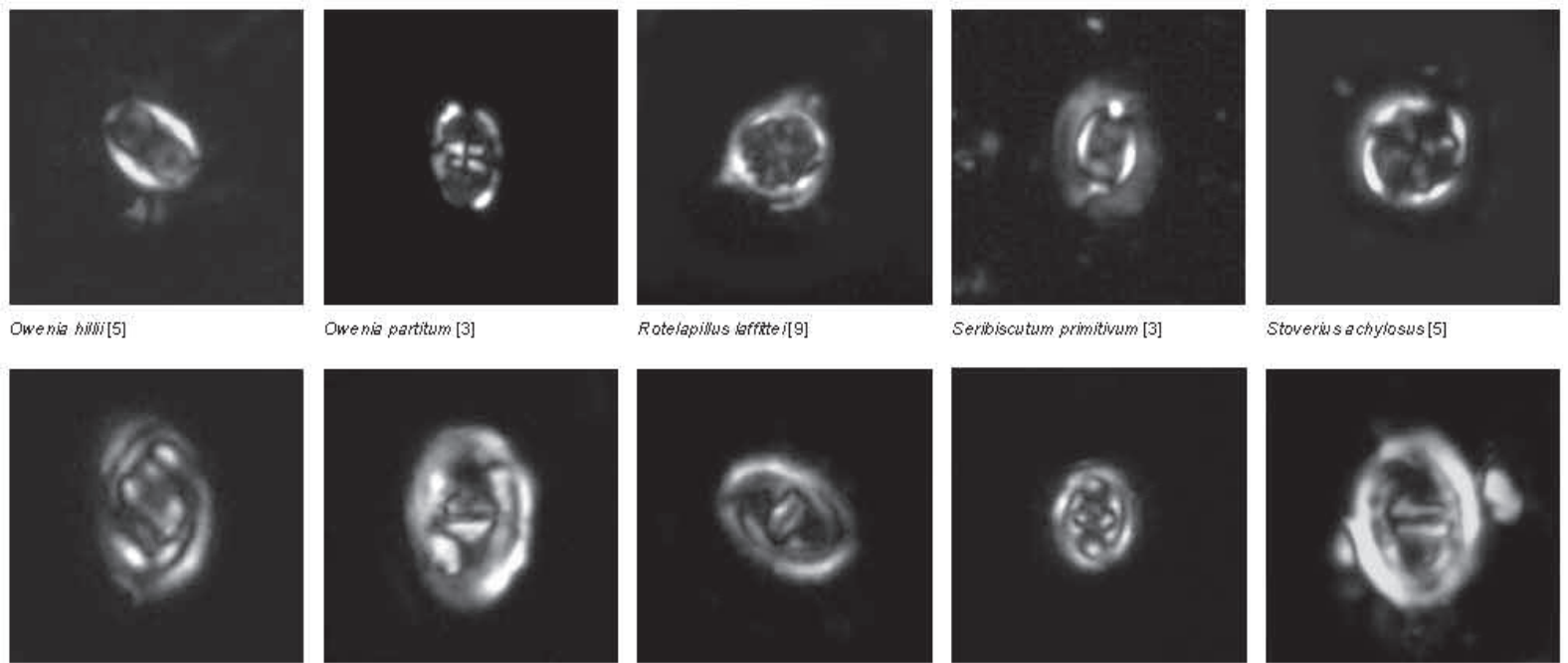

Zeugrhabdotus angeiozziae [7]

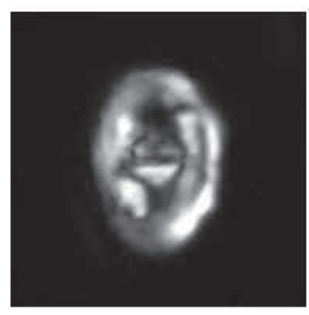

Zeugrhabdotus bicre scenticus [8]

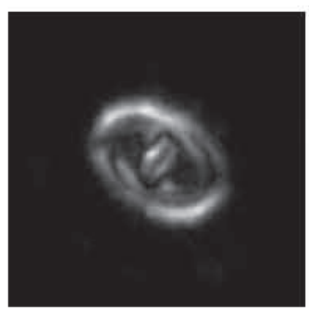

Zeugrhabdotus burwellensis[2]

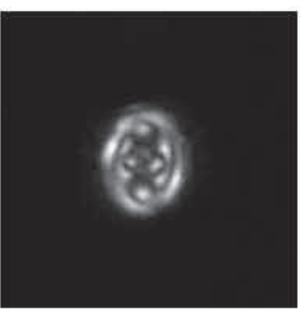

Zeugrhabdotus clans [6]

Stoverws achyiosus [5]
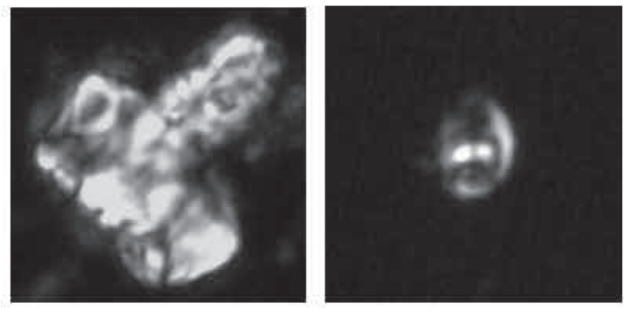

Zeugrhabdotus erectus [1 2]

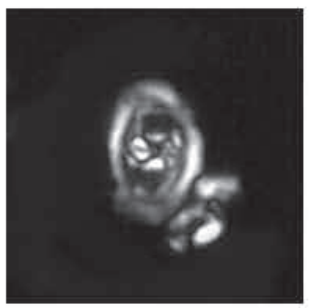

Zeugrhabdotus howei[2]

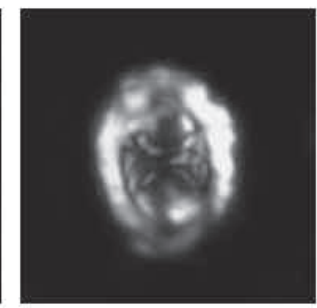

Zeugrhabdotus streetiae [4]

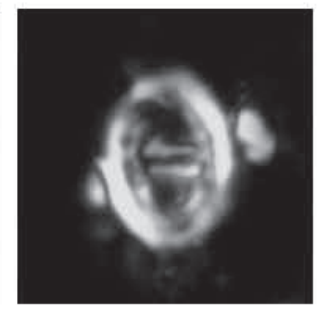

Zeugrhabdotus dipiogrammus [3]

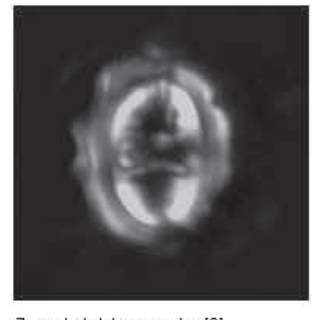

Zeugrhabdotus xenotus [2]

Supplementary Data 4B. Calcareous nannofossils observed in the Les Faïsses section. The species names and the sample number (in brackets) from which the calcareous nannofossil was photographed are given under each picture.

Axopodorhabdus albianus (Black, 1967) Wind and Wise, in Wise and Wind, 1977

Biscutum constans (Górka, 1957), Black, 1959 
Braarudosphaera africana Stradner, 1961

Braarudosphaera hockwoldensis Black, 1973

Broinsonia galloisii (Black, 1973) Bown, in Kennedy et al., 2002

Broinsonia matalosa (Stover, 1966) Burnett, in Gale et al., 1996

Bukrylithus ambiguus Black, 1971

Calcicalathina alta Perch-Nielsen, 1979

Calculites percernis Jeremiah, 1996

Chiastozygus bifarius Bukry, 1969

Chiastozygus litterarius (Górka, 1957) Manivit, 1971

Chiastozygus platyrhethus Hill, 1976

Corollithion signum Stradner, 1963

Cretarhabdus conicus Bramlette and Martini, 1964

Cretarhabdus striatus (Stradner, 1963) Black, 1973

Cribrosphaerella ehrenbergii (Arkhangelsky, 1912) Deflandre, in Piviteau, 1952

Crucicribrum anglicum Black, 1973

Cyclagelosphaera margerelii Noël, 1965

Cyclagelosphaera rotaclypeata Bukry, 1969

Cylindralithus nudus Bukry, 1969

Diazomatolithus lehmanii Noël, 1965

Discorhabdus ignotus (Gorka, 1957) Perch-Nielsen, 1968

Eiffellithus gorkae Reinhardt, 1965

Eiffellithus hancockii Burnett, 1998

Eiffellithus monechiae Crux, 1991

Eiffellithus turriseiffelii (Deflandre, in Deflandre and Fert, 1954) Reinhardt, 1965

Eprolithus floralis (Stradner, 1962) Stover, 1966

Flabellites oblongus (Bukry, 1969) Crux, in Crux et al., 1982

Gartnerago praeobliquum Jakubowski, 1986

Gartnerago stenostaurion (Hill, 1976) Perch-Nielsen, 1984

Haqius circumradiatus (Stover, 1966) Roth, 1978

Hayesites albienses Manivit, 1971

Helenea chiastia Worsley, 1971

Helicolithus compactus (Bukry, 1969) Varol and Girgis, 1994

Helicolithus trabeculatus (Górka, 1957) Verbeek, 1977

Lithraphidites carniolensis Deflandre, 1963

Loxolithus armilla (Black, 1959) Noël, 1965

Manivitella pemmatoidea (Deflandre, 1965) Thierstein, 1971 emend. Black, 1973

Nannoconus truittii Brönnimann, 1955

Nannoconus vocontiensis Deres and Achéritéguy, 1980

Orastrum perspicuum Varol, in Al-Rifaiy et al., 1990

Owenia dispar (Varol, in Al-Rifaiy et al., 1990) Bown, in Kennedy et al., 2000

Owenia hillii Crux, 1991

Owenia partitum (Varol, in Al-Rifaiy et al., 1990) Bown, in Kennedy et al., 2000

Percivalia fenestrata (Worsley, 1971) Wise, 1983

Prediscosphaera columnata (Stover, 1966) Perch-Nielsen, 1984

Prediscosphaera ponticula (Bukry, 1969) Perch-Nielsen, 1984

Prediscosphaera spinosa (Bramlette and Martini, 1964) Gartner, 1968

Radiolithus hollandicus Varol, 1992

Radiolithus planus Stover, 1966

Repagulum parvidentatum (Deflandre and Fert, 1954) Forchheimer, 1972

Retecapsa crenulata (Bramlette and Martini, 1964) Grün, 1975 
Retecapsa surirella (Deflandre and Fert, 1954) Grün, in Grün and Allemann, 1975

Rhagodiscus achlyostaurion (Hill, 1976) Doeven, 1983

Rhagodiscus amplus Bown, 2005b

Rhagodiscus angustus (Stradner, 1963) Reinhardt, 1971

Rhagodiscus asper (Stradner, 1966) Reinhardt, 1967

Rhagodiscus splendens (Deflandre, 1953) Verbeek, 1977

Rotelapillus laffittei (Noël, 1956) Noël, 1973

Scapholithus fossilis Deflandre in Deflandre and Fert, 1954

Seribiscutum primitivum (Thierstein, 1974) Filewicz et al., in Wise and Wind, 1977

Staurolithites gausorhethium (Hill, 1976) Varol and Girgis, 1994

Staurolithites mutterlosei Crux, 1989

Stoverius achylosus (Stover, 1966) Perch-Nielsen, 1986

Tegumentum stradneris Thierstein, in Roth and Thierstein, 1972

Tetrapodorhabdus coptensis Black, 1971

Tranolithus gabalus Stover, 1966 emend. Köthe, 1981

Tranolithus orionatus (Reinhardt, 1966) Reinhardt, 1966

Tubodiscus burnettiae Bown, in Kennedy et al., 2000

Watznaueria barnesiae (Black, 1959) Perch-Nielsen, 1968

Watznaueria biporta Bukry, 1969

Watznaueria britannica (Stradner, 1963) Reinhardt, 1964

Watznaueria fossacincta (Black, 1971) Bown, 1989

Zeugrhabdotus angelozziae Pérez Panera, 2012

Zeugrhabdotus bicrescenticus (Stover, 1966) Burnett in Gale et al., 1996

Zeugrhabdotus burwellensis (Black, 1972) Burnett, 1998

Zeugrhabdotus clarus Bown, 2005

Zeugrhabdotus diplogrammus (Deflandre, in Deflandre and Fert, 1954) Burnett in Gale et al., 1996

Zeugrhabdotus embergeri (Noël, 1958) Perch-Nielsen, 1984

Zeugrhabdotus erectus (Deflandre in Deflandre \& Fert, 1954) Reinhardt, 1965

Zeugrhabdotus howei Bown in Kennedy et al., 2000

Zeugrhabdotus noeliae Rood et al., 1971

Zeugrhabdotus streetiae Bown, in Kennedy et al., 2000

Zeugrhabdotus trivectis Bergen, 1994

Zeugrhabdotus xenotus (Stover, 1966) Burnett, in Gale et al., 1996

Supplementary Data 5. Complete list of calcareous nannofossil species identified in this work. 

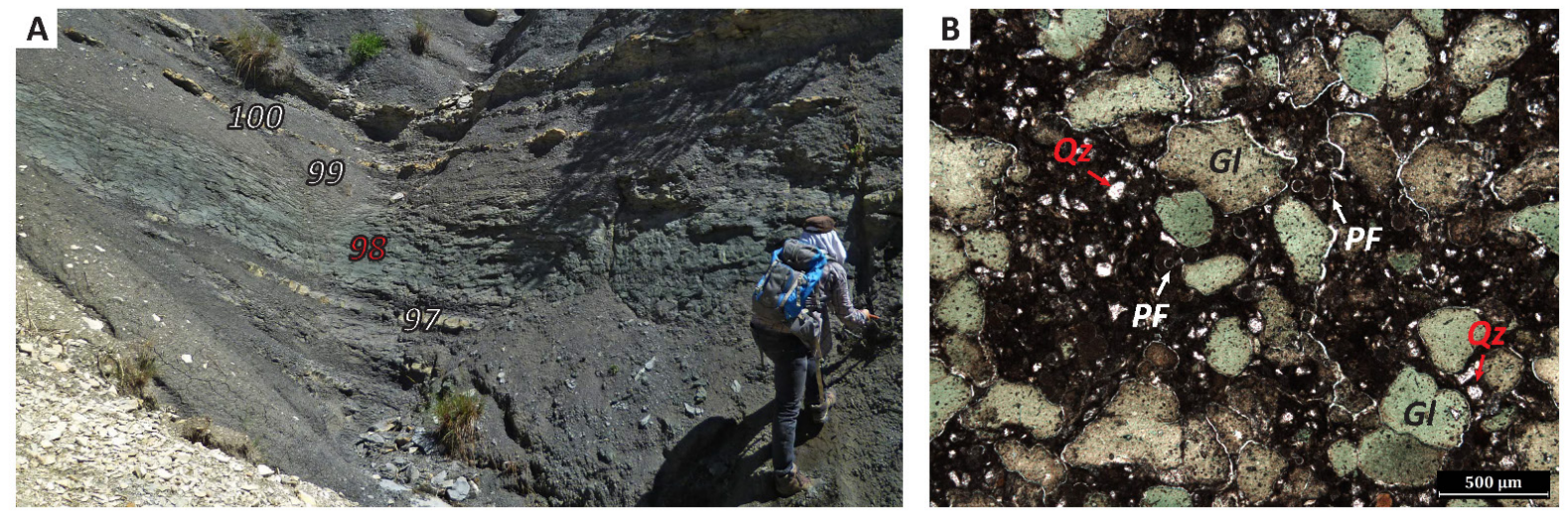

Supplementary Data 6. Facies illustrations of the glauconite-rich bed (98). A. Field photograph at La Sapée. B. Thin section photograph (Gl: glauconite, Qz: quartz, PF: planktic foraminifera) sampled at Les Faïsses.
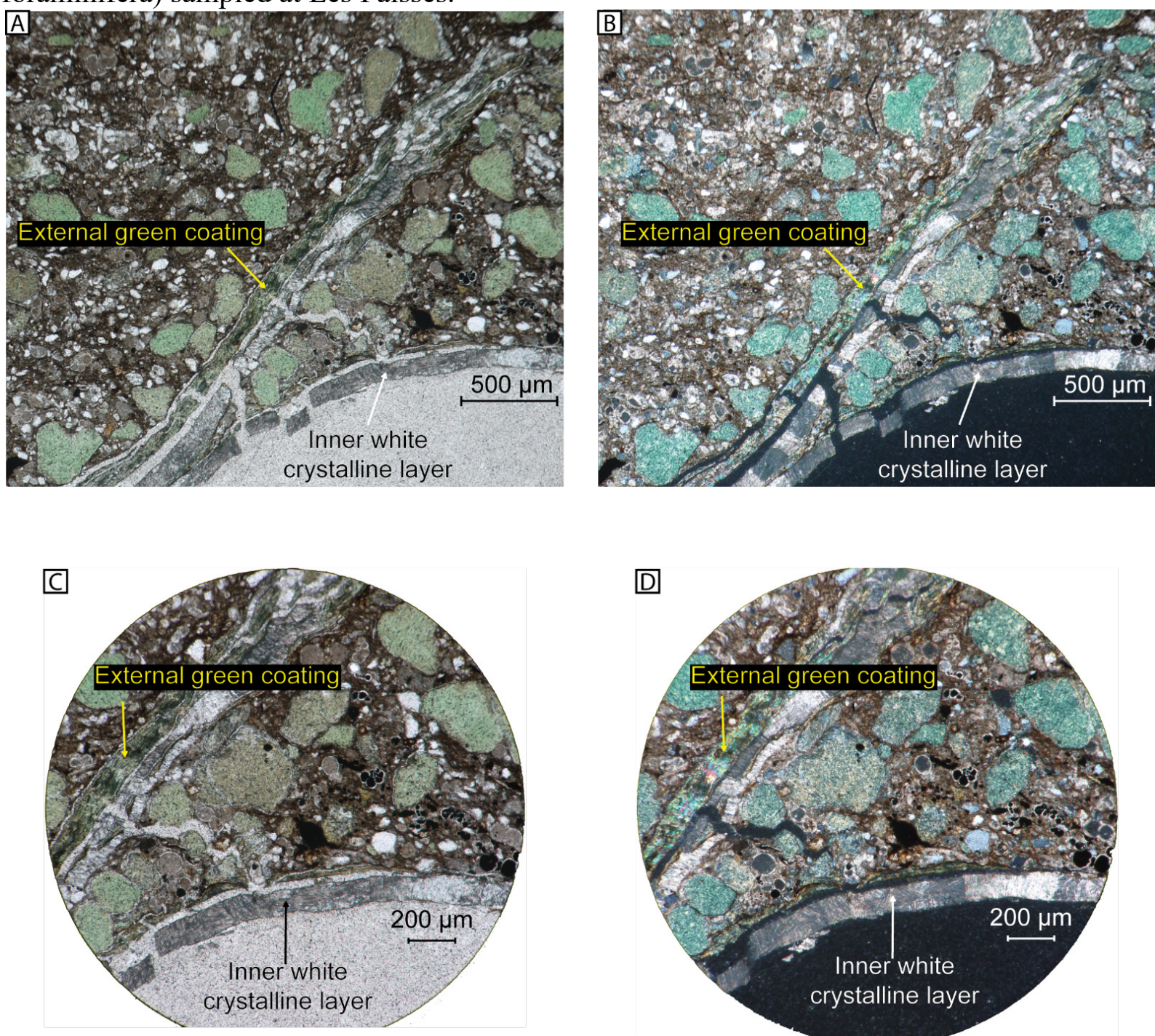

Supplementary Data 7. Photographs of a thin slide made through a fragment of ammonite sampled at Les Faïsses with observation of the external green coating and the inner white crystalline layer. A. LPNA $\mathrm{x} 4$ magnification. B. LPA $\mathrm{x} 4$ magnification. C. LPNA x12 magnification. D. LPA x12 magnification. 

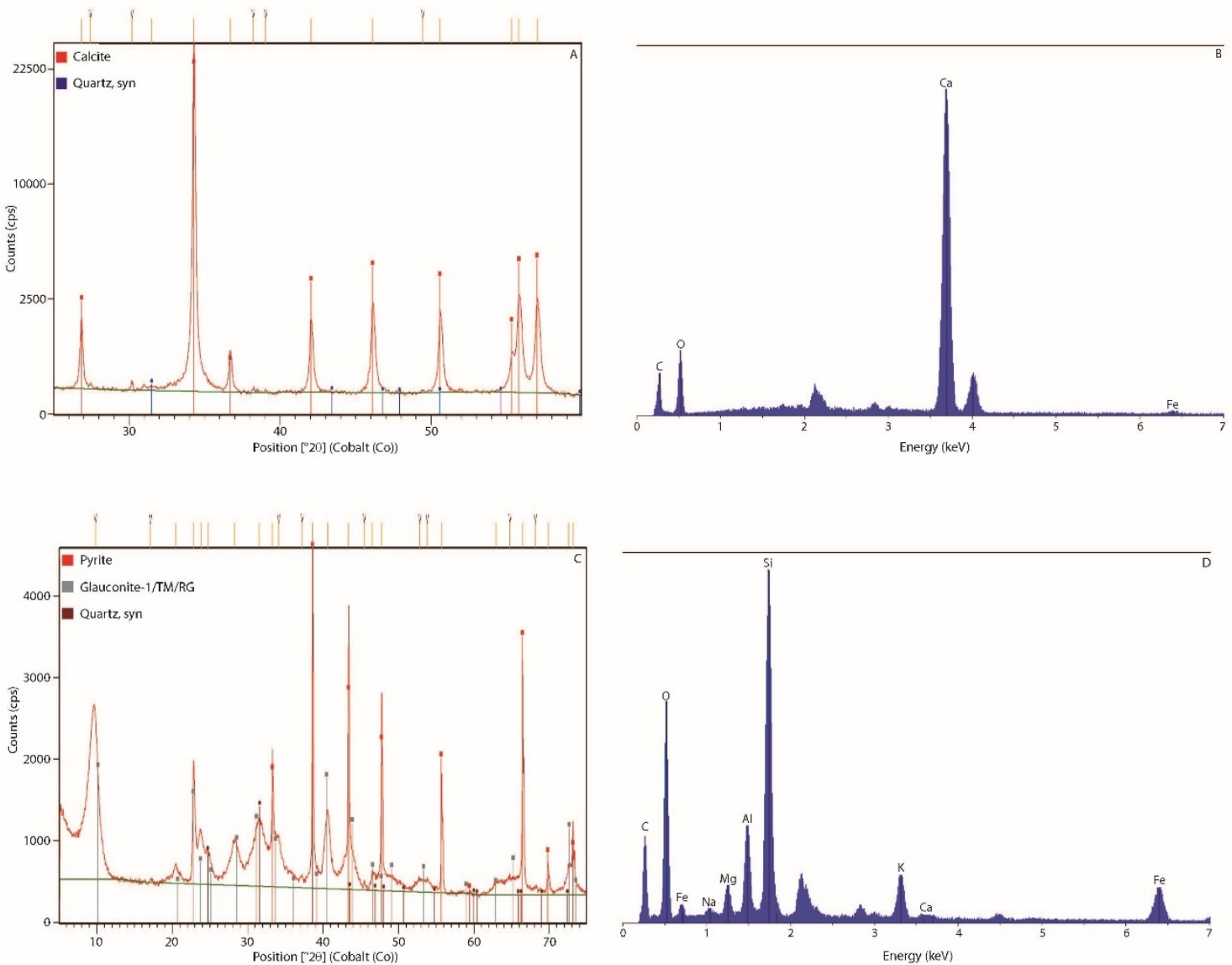

Supplementary Data 8. XRD and EDS analyses of the external green coating and inner white crystalline layer covering ammonites' moulds. A. XRD analysis of the inner white crystalline layer with identification of calcite. B. EDS analysis of the inner white crystalline layer with abundant $\mathrm{Ca}$ from calcite. $\mathrm{C}$. XRD analysis of the external green coating with identification of pyrite and glauconite. D. EDS analysis of the external green coating with $\mathrm{Si}$, $\mathrm{Al}, \mathrm{Mg}, \mathrm{K}, \mathrm{Na}$ and $\mathrm{Fe}$ from glauconite and $\mathrm{Fe}$ from pyrite. 

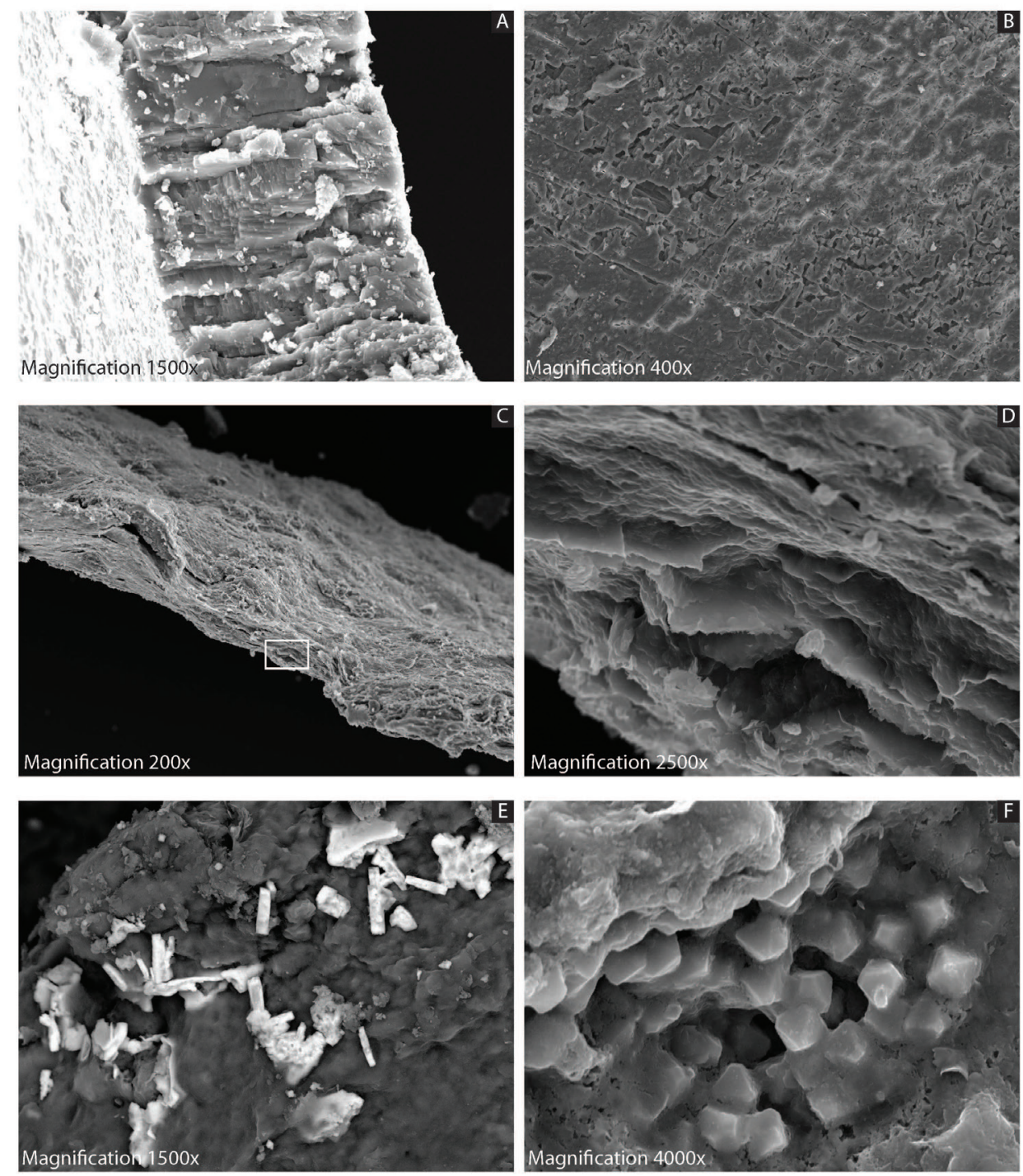

Supplementary Data 9. SEM pictures of the external green coating and the inner white crystalline layer covering ammonites' moulds. A. Cross-section of the inner white crystalline layer. B. Surface of the inner white crystalline layer. C and D. Cross-section of the external green coating. The white square in $\mathrm{C}$ represent the position of picture $\mathrm{D}$. E. Barite minerals in the external green coating. F. Pyrite minerals in the external green coating. 


\begin{tabular}{cccccc} 
Sample & $\mathrm{CaCO}_{3}(\%)$ & $\begin{array}{c}\delta^{13} \mathrm{C} \\
(\% \text { VPDB })\end{array}$ & $\begin{array}{c}\mathrm{SD}-\delta^{13} \mathrm{C} \\
(\% \circ \mathrm{VPDB})\end{array}$ & $\begin{array}{c}\delta^{18} \mathrm{O} \\
(\% \text { VPDB })\end{array}$ & $\begin{array}{c}\mathrm{SD}-\delta^{18} \mathrm{O} \\
(\% \circ \mathrm{VPDB})\end{array}$ \\
\hline FAl 1 & 27,80 & 1,51 & 0,04 & $-3,95$ & 0,07 \\
FAl 2 & 43,40 & 1,63 & 0,01 & $-4,32$ & 0,09 \\
FAl 3 & 39,50 & 1,67 & 0,00 & $-3,75$ & 0,01 \\
FAl 4 & 30,30 & 1,15 & 0,07 & $-4,32$ & 0,16 \\
FAl 5 & 28,50 & 1,31 & - & $-4,41$ & - \\
FAl 6 & 38,10 & 1,49 & 0,06 & $-4,21$ & 0,03 \\
FAl 7 & 36,80 & 1,30 & 0,12 & $-4,11$ & 0,10 \\
FAl 8 & 34,00 & 1,60 & 0,14 & $-3,69$ & 0,32 \\
FAl 9 & 45,20 & 1,53 & 0,11 & $-4,50$ & 0,16 \\
FAl 10 & 28,00 & 1,37 & 0,03 & $-4,36$ & 0,01 \\
FAl 11 & 37,30 & 1,36 & 0,05 & $-4,40$ & 0,05 \\
FAl 12 & 59,60 & 0,72 & 0,04 & $-5,48$ & 0,08 \\
FAl 13 & 36,90 & 1,10 & 0,06 & $-4,77$ & 0,07 \\
FAl 14 & 41,40 & 1,40 & 0,02 & $-4,96$ & 0,04 \\
FAl 15 & 27,40 & 1,56 & 0,05 & $-4,18$ & 0,11 \\
FAl 16 & 33,40 & 0,58 & 0,03 & $-4,82$ & 0,10 \\
FAl 17 & 26,70 & 1,58 & 0,00 & $-4,15$ & 0,03 \\
FAl 18 & 43,80 & 1,31 & 0,03 & $-5,19$ & 0,16
\end{tabular}

Table S1. Stable isotope composition of bulk carbonate and calcium carbonate contents of the studied succession at Les Faïsses. 